\title{
Press Freedom and Fair Trials in Kansas: How Media and the Courts Have Struggled to Resolve Competing Claims of Constitutional Rights
}

\author{
M.A. "Mike” Kautsch"
}

\section{INTRODUCTION}

Kansas trial judges and the news media often have clashed over the meaning of the First ${ }^{1}$ and Sixth ${ }^{2}$ Amendments to the U.S. Constitution. The media assume that the freedom of the press, protected by the First Amendment, gives them the right to report comprehensively on court cases. Thus, the media may publicize information that is prejudicial to criminal defendants but is inadmissible as evidence in court. Judges, however, assume that they have a high duty to protect defendants' Sixth Amendment right to a fair trial—one in which jurors are impartial and have not been influenced by prejudicial publicity. Judges may try to limit publicity to maintain the fairness of criminal or civil proceedings or to protect the privacy of trial participants. Because of their different outlooks, judges and the media in Kansas can find themselves in sharp conflict.

An example of this conflict occurred in Saline County, Kansas, where a newspaper was covering the jury trial of a defendant who had been charged with rape. When the trial was in its third day and was expected to end, the newspaper reported that the defendant recently had been sentenced in an earlier sex-related criminal case in a different county. ${ }^{3}$ The district judge in the Saline County rape trial promptly

* Professor of Law, University of Kansas School of Law. This Article is an outgrowth of an ongoing effort to identify trends in access to court proceedings and records nationally. With thanks, I acknowledge the superb work of a former research assistant, Jamie Huffman Jones, now an associate with Friday Eldredge \& Clark in Little Rock, Arkansas. Others who provided significant help include Erin DeKoster, a current research assistant. Thanks also to members of the Kansas Law Review, especially Justin Hendrix and Mike Crabb, for their remarkable professionalism as editors.

1. "Congress shall make no law ... abridging the freedom of speech, or of the press ...." U.S. CONST. amend. I.

2. "In all criminal prosecutions, the accused shall enjoy the right to a speedy and public trial, by an impartial jury ...." U.S. CONST. amend. VI.

3. David Clouston, Mistrial Declared Because of Article, SALinA J., Aug. 7, 2008, available at http://www.salina.com/news/story/mistrial-8-7-08. 
declared a mistrial, saying the article may have prejudiced the jurors against the defendant. ${ }^{4}$ The judge suggested that the newspaper had not acted in the public interest and had published the article merely to boost circulation and profits. ${ }^{5}$ The criticism was echoed in reader comments posted on the newspaper's website, one stating: "If the [newspaper] cared about the victim, they would not have printed the article. Anything for a buck! Even putting [the victim] through hell again." Responding, the newspaper's editor and publisher expressed concern for the victim but said that the paper's practice was to publish information as it became available, "not according to a judge's wishes. It would be irresponsible, and a disservice to our readers, to allow government or any other public institution to make news decisions."

A second example, from Johnson County, Kansas, concerns a plastic surgeon who disposed of an office computer by placing it on the curb by his home. He had removed the computer's random access memory and anticipated that the city trash collectors would take the computer. A private passer-by picked up the computer, however, and reactivated it. ${ }^{8}$ He discovered that it contained personal information about the surgeon's patients, including "before-and-after" photographs of their cosmetic treatment. $^{9} \quad$ The passer-by then gave the computer to a television station. ${ }^{10}$ The station's news staff began to contact patients identified on the computer, and prepared to broadcast a report that the surgeon had discarded the computer without first purging it of sensitive information. The surgeon, however, aimed to prevent the newscast, and convinced a judge to issue a restraining order barring the station from broadcasting

\footnotetext{
4. Id.

5. Id.

6. Posting of Anonymous to Join the Discussion, http://www.salina.com/news/story/mistrial8-7-08 (Aug. 8, 2008).

7. Tom Bell, Editorial, A Surprise Decision in Mistrial, SAlINA J., Aug. 9, 2008, available at http://www.salina.com/print/rape-mistrial-edit. Each day of the rape trial, the presiding judge, the Hon. Jerome Hellmer, admonished the jurors to avoid news about the case. Clouston, supra note 3. When the article about the defendant was published by the Salina Journal, however, he declared a mistrial in response to a defense attorney's request and without objection from the prosecution. Id. Before the mistrial declaration, jurors were not questioned about whether they had seen the Journal article. Id. County Prosecutor Christina Trocheck said questioning the jurors would not have been effective, indicating that it only would have made them suspicious of the defendant. Id. The article contained information that already had been published and posted online by a newspaper in the county where the defendant had previously been convicted. Id. Tom Bell, editor and publisher of the Journal, emphasized that the article was published on an inside page of the paper under a routine headline, and he said it was "nothing out of the ordinary." Bell, supra.

8. Dan Margolies, Doctor Dropping Suit Against KCTV, KAN. CiTY STAR, July 15, 2005, at C3.

9. Id.

10. Id.
} 
photographs and "any data or information" found on the computer. Condemning the order as an "insidious form of government censorship" and an "obvious violation of the First Amendment," the station unsuccessfully challenged it in district court. The station then appealed to the Kansas Supreme Court. ${ }^{11}$

A third example occurred in a McPherson County, Kansas, capital murder case, where a judge ordered that defense attorneys and prosecutors not release any of their motions or other court papers to the media. $^{12}$ He directed that the papers be given to him first so that he could determine whether, if filed as public records, they would result in prejudicial publicity to the defendant. ${ }^{13}$ He said that, after personally reviewing the papers, he would decide whether the clerk of court should file them. The judge understood that, before actually sealing a record, he would have to conduct a hearing and specifically find that making the record public would be prejudicial to the defendant. ${ }^{14}$ Three Kansas newspapers and the Kansas Press Association, however, appealed to the Kansas Supreme Court, arguing that the judge was not empowered to keep the records secret before conducting a hearing on whether to seal them. ${ }^{15}$

11. This summary of the dispute is based on petitions, memoranda, and other documents filed by Monarch Plastic Surgery, P.A. and Meredith Corporation d/b/a KCTV5 in the District Court of Johnson County, Kansas, Case No. 05-CV-04838, between June 17 and June 28, 2005, and later on appeal with the Kansas Supreme Court in Case No. 2005-94734 (on file with author). Attorney Bernard J. Rhodes of Kansas City, Missouri, who represented KCTV5, was the one who characterized the restraint order as "insidious." See sources cited supra. Dr. Daniel Bortnick of Monarch Plastic Surgery was the surgeon who had discarded the computer and sought the order. See sources cited supra. It originally was issued ex parte June 17, 2005, against KCTV5 by the Hon. Kevin P. Moriarty, Johnson County District Court judge. See sources cited supra. While the matter was pending before the Kansas Supreme Court, KCTV5, which is based in Fairway, Kansas, broadcast a report on June 30, 2005, about the surgeon discarding the office computer. The broadcast focused on the fact that the computer should have been purged before being discarded, and the station's news director said there had been a false belief that "we were getting ready to broadcast personal information that we never had plans to do and never would do."” Margolies, supra note 8. After the broadcast and as the matter was pending before the Kansas Supreme Court, Monarch Plastic Surgery moved in Johnson County District Court to dismiss its case against KCTV5, the station turned over the patient information and destroyed copies, the restraint order was dissolved in district court, and the Kansas Supreme Court declared the case moot. Id.; Notice of Dismissal, Meredith Corp. v. Moriarty, No. 2005-94734 (Kan. Sept. 20, 2005).

12. Roxana Hegeman, Ex-Mainer Charged with Killing Children, BANGOR DaILY News, Oct. 12, 1999, available at 1999 WLNR 844588.

13. Id.; Associated Press, Judge Delays Decision on Records Access in Lindsborg Slayings, Wichita EAgLe, Nov. 2, 1999, at 11A.

14. Associated Press, supra note 13.

15. Id. The restriction on access to records was imposed by the Hon. Carl B. Anderson Jr., judge in the Kansas Ninth Judicial District. See id. Prosecution and defense attorneys both opposed the media's request for more access to court records in the case. Id. Assistant Kansas Attorney General Al Walczak said that "publicity in a case of this magnitude would be prejudicial in a community with a small population." Id. Michael W. Merriam of Topeka, Kansas, who represented 
The purposes of this Article are to 1) survey significant free press/fair trial controversies in Kansas, 2) highlight recurrent and emerging issues faced by the state's judges and journalists, and 3) provide an overview of the law on media and public access to Kansas court proceedings and records. The Article begins with a review of landmark precedents through which the United States Supreme Court charted a course for resolving free press/fair trial issues in Kansas and all other states. The review takes into account precedents that clarify the responsibility of trial judges to balance First and Sixth Amendment interests. The review is intended to illuminate how the precedents limit judges' latitude to impose restraints - or "gag orders" - on speech and publication and their authority to close courts as means of preventing prejudicial publicity. The Article then addresses the issue of prejudicial publicity, with emphasis on the Kansas experience. The focus is on criminal defendants' claims for mistrials, media objections to gag orders, and when criminal, as well as civil, proceedings are presumed to be open or may be closed. The next part of the Article surveys Kansas law, and to some extent national law, on the accessibility of court records, both in criminal and civil matters. Because courts in Kansas have not dealt directly with some noteworthy free press/fair trial issues, the Article reviews certain significant legal developments in other jurisdictions. The Tenth Circuit is among federal jurisdictions that are taken into account, because it includes Kansas. The Article concludes with a consideration of selected issues in access to court proceedings and records. The issues include the media's standing to object to judicially imposed restrictions and the nature of court rules on photographing or televising proceedings.

\section{FREE PRESS/FAir TRIAL LANDMARK CASES}

Landmark decisions by the United States Supreme Court heavily influenced the Kansas approach to protecting trials from the effects of prejudicial publicity.

the media, expressed a contrary view, saying: "It is a common misconception to believe an open hearing and open records - even in a capital case - will create prejudice .... [O]penness enhances basic fairness of the trial." Id. Ultimately, records became public when the defendant entered a plea of guilty. Roxana Hegeman, Associated Press, Lindsborg Murderer Confesses-In a Plea Agreement to Avoid the Death Penalty, A Father Admits to the Gruesome Killing of his Three Children, Wichita EAgLE, June 13, 2000, at 1A. The Kansas Supreme Court dismissed the matter as moot in Hutchinson Publishing Co. v. Anderson, No. 84820 (Kan. Feb. 29, 2000). 


\section{A. The Responsibility of Trial Judges}

In the 1960s, the United States Supreme Court handed down two significant rulings regarding trial judges' responsibility to protect criminal defendants from prejudicial publicity. In a 1965 case, Estes $v$. Texas, Billy Sol Estes had been convicted of swindling. ${ }^{16}$ He was a wellknown, newsworthy figure, once characterized as a "confidence man who bilked Texas farmers out of millions of dollars."17

After a Texas appellate court affirmed his conviction, Estes appealed to the United States Supreme Court, claiming that his right to due process had been denied because of prejudicial, televised news coverage of his case. ${ }^{18}$ After reviewing the record, the Supreme Court found that there indeed had been "[m]assive pretrial publicity"19 and that the televised trial coverage had resulted "in a public presentation of only the State's side of the case." 20

In a five to four decision, the Supreme Court reversed Estes's conviction. Writing for the majority, Justice Tom C. Clark took a firm stand against televised trials. He stressed that a trial judge's responsibility is to "make certain that the accused receives a fair trial." 21 In his view, if a judge permits television in the courtroom, it becomes an "ever-present distraction." 22 The concurring opinion by Chief Justice Earl Warren added that the appropriate use of television cameras "does not extend into an American courtroom." 23 Television reporters, he indicated, must leave their cameras at the courthouse door because, inside, they only have the "rights of the general public, namely, to be present, to observe the proceedings, and thereafter, if they choose, to report them." 24 In a second concurring opinion, Justice John M. Harlan was less resolute than Justice Clark on the issue of television cameras in courtrooms. ${ }^{25}$ In a dissent, Justice Potter Stewart strongly cautioned

\footnotetext{
16. 381 U.S. 532, 534 n.1 (1965).

17. Wayne King, Estes Links Johnson to Plot, N.Y. Times, Mar. 24, 1984, at 9.

18. Estes, 381 U.S. at $534-35$.

19. Id. at 535 .

20. Id. at 551 .

21. Id. at 548 .

22. Id.

23. Id. at 585 (Warren, C.J., concurring).

24. Id. at 586.

25. Id. at 596 (Harlan, J., concurring). Justice Harlan said that conditions eventually could change, so that television coverage of trials may "be subject to re-examination in accordance with the traditional workings of the Due Process Clause." Id.
} 
against taking a hard line against television coverage of court proceedings. $^{26}$

A year after deciding Estes, the United States Supreme Court again looked at trial judges' responsibility to manage newsworthy trials. In Sheppard v. Maxwell, the Supreme Court found that a trial judge had failed to protect the defendant "from the inherently prejudicial publicity which saturated the community and to control disruptive influences in the courtroom ...."27 The defendant was Sam Sheppard, a doctor of osteopathic medicine who specialized in surgery. ${ }^{28} \mathrm{He}$ had been convicted of fatally bludgeoning his wife in 1954 at their home in Cleveland, Ohio. ${ }^{29}$ The Supreme Court, with a lone dissent, ${ }^{30}$ held that Sheppard had not received due process and ordered a new trial. ${ }^{31}$ Justice Clark, again writing for the majority, noted that the publicity in Estes "was not nearly as massive and pervasive" as in Sheppard. ${ }^{32}$ A dramatic illustration of the intense publicity in Sheppard occurred during a threeday inquest - televised live from a high school gymnasium - featuring a lengthy examination of Sheppard, who was not represented by counsel, and which "ended in a public brawl." 33 Then, during a nine-week trial, "bedlam reigned" in the courtroom. ${ }^{34}$ For example, when the judge met with counsel in chambers, "news media representatives so packed the judge's anteroom that counsel could hardly return from the chambers to the courtroom. The reporters vied with each other to find out what counsel and the judge had discussed, and often these matters later appeared in newspapers accessible to the jury." 35

Justice Clark noted that "unfair and prejudicial news comment on

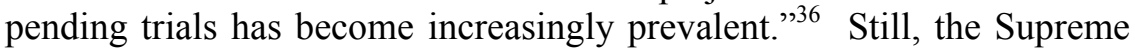
Court was not willing to place direct restraints on the media's traditional

26. Id. at 613-14 (Stewart, J., dissenting). Justice Stewart said the record made it "crystal clear" that the trial judge had been in command of the Estes case and that the trial was a "mundane affair." Id. at 613. He also expressed concern that the majority's reasoning was "disturbingly alien to the First and Fourteenth Amendments' guarantees against federal or state interference with the free communication of information and ideas." Id. at 614 .

27. 384 U.S. 333, 363 (1966).

28. Sheppard v. Maxwell, 231 F. Supp. 37, 39 (S.D. Ohio 1964), rev'd, 346 F.2d 707 (6th Cir. 1965), rev'd, 384 U.S. 333 (1966).

29. Id. at 40.

30. Sheppard, 384 U.S. at 363 (Black, J., dissenting).

31. Id. at 362-63 (majority opinion).

32. Id. at 353 .

33. Id. at 354

34. Id. at 355 .

35. Id. at 344 .

36. Id. at 362 . 
freedom to report on court proceedings. ${ }^{37}$ Justice Clark characterized what happens in a courtroom as "“public property.",38 Nevertheless, he stressed that trial judges are responsible for managing proceedings to protect a defendant's right to a fair trial. ${ }^{39}$ He indicated that judges, to fulfill their responsibility, may take the following measures: question prospective jurors closely during voir dire about their possible exposure to prejudicial publicity; ${ }^{40}$ limit reporters to a specified location within the courtroom and prescribe and enforce conduct rules for them; ${ }^{41}$ prohibit trial participants, including any lawyer, party, witness, or court official, from divulging prejudicial matters to the media; ${ }^{42}$ request that city and county officials prevent any of their employees who have information about a case from disseminating $\mathrm{it}^{43}{ }^{43}$ warn reporters about the "impropriety" of broadcasting or publishing information that is not admissible as evidence in the proceedings; ${ }^{44}$ and when a reasonable likelihood exists that prejudicial publicity will prevent a fair trial, continue the case, change the venue, or sequester the jury. ${ }^{45}$

\section{B. Gag Orders as Unconstitutional Prior Restraints}

As concern about prejudicial publicity increased throughout the U.S. judicial system, the American Bar Association (ABA) developed standards for the conduct of trials. ${ }^{46}$ The ABA standards, published in 1968, placed heavy emphasis on "safeguarding the interests of a fair trial." 47 In fact, the emphasis on fairness was so heavy that skeptics questioned whether the ABA had "seriously underestimated the interests

\footnotetext{
37. Id. at 350 .

38. Id. (quoting Craig v. Harney, 331 U.S. 367, 374 (1947)).

39. Id. at $350-51$.

40. See id. at 345,347 (discussing instances when jurors were exposed to outside influences).

41. Id. at 358 .

42. Id. at 361 .

43. Id. at 362 .

44. Id. at 362 .

45. Id. at 363; see also Gannett Co. v. DePasquale, 443 U.S. 368, 441 (1979) (Blackmun, J., dissenting) (citing THE AMERICAN BAR ASSOCIATION STANDARDS RELATING TO THE Administration of Criminal Justice: Fair Trial and Free Press $\S 8-3.2$ (2d ed. 1978) [hereinafter ABA STANDARDS 2d ed.]) (listing continuance, severance, change of venue, change of venire, voir dire, peremptory challenges, sequestration, and admonition of the jury as alternative measures). Regarding Gannett Co. v. DePasquale generally, see infra notes 64-70 and accompanying text.

46. ABA Standards for Criminal Justice: Fair Trial And Free Press ix (3d ed. 1992) [hereinafter ABA STANDARDS $3 \mathrm{~d}$ ed.].

47. Id.
} 
of a free press. ${ }^{, 48}$ Meanwhile, judges across the country were asserting strong control over their courtrooms. As a result, there was "a dramatic rise in the number of broad gag orders issued to enjoin any extrajudicial comment on a pending case." 49

Tension over the problem of prejudicial publicity reached a breaking point in 1975 in Nebraska. Authorities charged a man, Erwin Simants, with fatally shooting six members of a Nebraska family. ${ }^{50}$ Public interest in the case was high, and the media prepared to cover a hearing on whether Simants should be bound over for trial. A judge, however, issued a gag order, prohibiting the media "from releasing 'for public dissemination in any form or manner whatsoever any testimony given or evidence adduced during the preliminary hearing." 51

The media appealed, challenging the judge's order as a prior restraint that violated the First Amendment. The Nebraska Supreme Court modified the order, limiting its scope somewhat, but otherwise denied the media's appeal. ${ }^{52}$ After reviewing the United States Supreme Court's opinion in Sheppard, the Nebraska Supreme Court said it was "clear that the Supreme Court of the United States has never said, in the context with which we are here concerned, that such restraints may never be imposed when necessary to assure trial by an impartial jury." ${ }^{, 5}$

In Nebraska Press Ass'n v. Stuart, however, the United States Supreme Court found that the gag order in the Simants case was an unconstitutional prior restraint. ${ }^{54}$ Writing for the majority, Chief Justice Warren E. Burger said that the order "violated settled principles: '[T]here is nothing that proscribes the press from reporting events that transpire in the courtroom." 55 The Court indicated that a gag order against the media is unconstitutional unless prejudicial publicity poses a clear and present danger to the fairness of a trial. ${ }^{56}$ Therefore, before issuing a gag order against the media, a trial judge must "determine (a) the nature and extent of pretrial news coverage; (b) whether other measures would be likely to mitigate the effects of unrestrained pretrial publicity; and (c)

48. Id.

49. Id.

50. State v. Simants, 236 N.W.2d 794, 796 (Neb. 1975), rev'd sub nom. Neb. Press Ass'n v. Stuart, 427 U.S. 539 (1976).

51. Id. at 797 .

52. Id. at $805-06$.

53. Id. at 800 .

54. 427 U.S. 539,570 (1976).

55. Id. at 568 (quoting Sheppard v. Maxwell, 384 U.S. 333, 362-63 (1966)). Other justices filed concurring opinions; there was no dissent.

56. Id. at 563 . 
how effectively a restraining order would operate to prevent the threatened danger." $" 57$

In reviewing the gag order in the Simants case, the United States Supreme Court said that the judge should have determined the "probable extent of publicity" about the case ${ }^{58}$ considered "whether measures short of an order restraining all publication" would have protected the defendant's right to a fair trial, ${ }^{59}$ and assessed the "probable efficacy" of a prior restraint "as a workable method" for maintaining fairness of the proceedings. ${ }^{60}$

\section{Closure of Court Proceedings Presumed Unconstitutional}

Prejudicial publicity continued to be a pressing concern for trial judges throughout the United States. Under Sheppard, judges were required to control their courtrooms to protect defendants' Sixth Amendment right to a fair trial. ${ }^{61}$ Yet, Nebraska Press made clear that judges' courtroom control was not unlimited. ${ }^{62}$ They rarely, if ever, could constitutionally restrain the media from reporting what they learned in open court. ${ }^{63}$ Thus, judges turned to an alternative way to prevent prejudicial publicity, which was simply to close the court.

Media challenges to this approach resulted in an important series of United States Supreme Court decisions on the openness of courts and on trial judges' responsibility to protect defendants against prejudicial publicity.

A 1979 case, Gannett Co. v. DePasquale, centered on objections by Rochester, New York newspapers to a judge's closure of a pre-trial hearing in a highly publicized murder case. ${ }^{64}$ The purpose of the hearing was to determine whether incriminating statements that defendants had given to police were involuntary and therefore should be suppressed. ${ }^{65}$ The judge granted a motion-made by defense attorneys without objection from the prosecution-to close the hearing because of an "unabated buildup of adverse publicity" about the case. ${ }^{66}$ After hearing

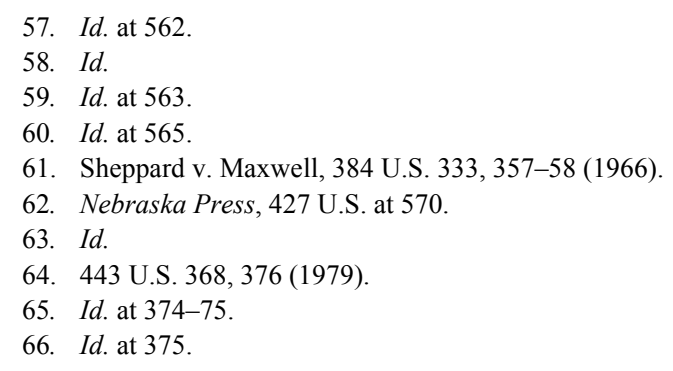


objections to his closure order, the judge determined that "an open suppression hearing would pose a "reasonable probability of prejudice" to the defendants. ${ }^{67}$

The Supreme Court upheld the trial judge, ${ }^{68}$ finding that the media and the public "have no constitutional right under the Sixth and Fourteenth Amendments to attend criminal trials" ${ }^{\prime 69}$ and that the judge's determination to close the pre-trial suppression hearing was "consistent with any right of access the [media] may have had under the First and Fourteenth Amendments."70

The Supreme Court, however, did not treat DePasquale as a controlling precedent a year later in Richmond Newspapers, Inc. $v$. Virginia, when the media objected to closure of a trial. ${ }^{71}$ Before the closure, Virginia authorities had placed the defendant, John Paul Stevenson, on trial three times in open court. ${ }^{72}$ In the first trial, he had been convicted of fatally stabbing a motel manager, but won a reversal by claiming improper use of evidence against him. ${ }^{73}$ The state's second and third attempts to try him on the murder charge ended in mistrials. ${ }^{74}$ Before the fourth trial, the judge granted a defense motion for closure to prevent public disclosures of testimony by witnesses against Stevenson. ${ }^{75}$ The prosecution did not object. ${ }^{76}$

Writing for the plurality, Chief Justice Burger noted that the issue in DePasquale had been whether a judge could constitutionally close a pretrial proceeding, as opposed to a trial. ${ }^{77} \mathrm{He}$ also noted that DePasquale had not addressed whether the First Amendment, as opposed to the Sixth, guaranteed a right of the media and the public to attend trials. ${ }^{78}$ Because closure of a trial was directly at issue in Richmond Newspapers, Chief Justice Burger seized the opportunity to declare that "the First

67. Id. at 376 .

68. Id. at 394. Justice Potter Stewart wrote the majority opinion, with concurrences by others. Justice Blackmun also filed a partial dissent, however, in which three justices joined. He essentially took the position that the Sixth Amendment protects the media and the public's interest in attending criminal trials. Id. at 432-33 (Blackmun, J., concurring in part and dissenting in part).

69. Id. at 391 (majority opinion).

70. Id. at 392 .

71. 448 U.S. 555, 563-64 (1980).

72. Id. at 559 .

73. Id. (citing Stevenson v. Commonwealth, 237 S.E.2d 779, 780 (Va. 1977)).

74. Id.

75. Id. at 560

76. Id.

77. Id. at 564. Justices White and Stevens concurred; Justices Brennan, Marshall, Stewart, and Blackmun concurred in the judgment; Justice Rehnquist dissented.

78. Id. 
Amendment guarantees of speech and press, standing alone, prohibit government from summarily closing courtroom doors which had long been open to the public at the time that Amendment was adopted."79

Chief Justice Burger characterized the courtroom as "a public place where the people generally - and representatives of the media - have a right to be present." ${ }^{, 8}$ Historically, he said, criminal trials were "presumptively open." " Also noteworthy, he said, was the relationship between the openness of a trial and its "proper functioning." 82 The presence of the media and the public "gave assurance that the proceedings were conducted fairly to all concerned, and it discouraged perjury, the misconduct of participants, and decisions based on secret bias or partiality." ${ }^{83}$ Judges may close a trial, according to Chief Justice Burger, only if they establish, through findings articulated in the record, that alternatives would not be effective and that there is an "overriding interest" in closure. ${ }^{84}$

Concurring in the judgment, Justice William J. Brennan stressed the tradition and value of the openness of trials. The First Amendment, he said, "embodies more than a commitment to free expression and communicative interchange for their own sakes; it has a structural role to play in securing and fostering our republican system of selfgovernment." ${ }^{85}$ Justice Brennan explained:

Implicit in this structural role is not only "the principle that debate on public issues should be uninhibited, robust, and wide-open," but also the antecedent assumption that valuable public debate - as well as other civic behavior - must be informed. The structural model links the First Amendment to that process of communication necessary for a democracy to survive, and thus entails solicitude not only for communication itself, but also for the indispensable conditions of meaningful communication. ${ }^{86}$

In four cases between 1982 and 1986, the United States Supreme Court further established that criminal proceedings generally would be open to the media and the public. In the first case, Globe Newspaper Co. v. Superior Court, the Supreme Court struck down a state statute that

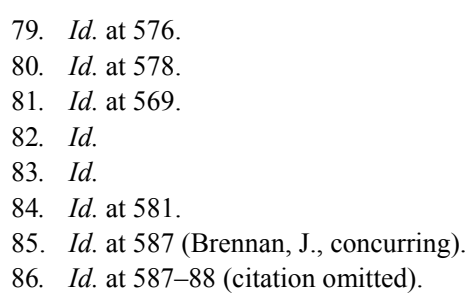


mandated closure of trials during testimony by minor rape victims. ${ }^{87}$ Proponents of the statute had asserted that it protected the privacy and psychological well-being of sex-offense victims. ${ }^{88}$ Because the statute protected the victims, the proponents argued, they would be more willing to come forward and report crimes to the police. ${ }^{89}$ The Court, however, held that the statute mandating closure of trials was not effective in protecting the victims. ${ }^{90}$ Nothing prevented the media from learning about the trial through a transcript of the proceedings or from knowledgeable court personnel or others. ${ }^{91}$ Writing for the majority, Justice Brennan said that trial judges may consider closing trials only on a case-by-case basis, explaining:

[T] he circumstances under which the press and public can be barred from a criminal trial are limited; the State's justification in denying access must be a weighty one. Where, as in the present case, the State attempts to deny the right of access in order to inhibit the disclosure of sensitive information, it must be shown that the denial is necessitated by a compelling governmental interest, and is narrowly tailored to serve that interest. ${ }^{92}$

Then, in Press-Enterprise Co. v. Superior Court (Press-Enterprise I), the Supreme Court reviewed its limitations on closure of criminal court proceedings. ${ }^{93}$ A defendant had been charged with the rape and murder of a teenage girl. ${ }^{94}$ During a voir dire examination of prospective jurors - an event that lasted six weeks - the trial judge closed the proceeding to the media and the public, and then denied a newspaper's request for a transcript. ${ }^{95}$ In his majority opinion, Chief Justice Burger called the extended closure "incredible" and said the judge's order and denial of a transcript were unconstitutional. ${ }^{96}$ He said:

The presumption of openness may be overcome only by an overriding interest based on findings that closure is essential to preserve higher values and is narrowly tailored to serve that interest. The interest is to

87. 457 U.S. 596, 598, 610-11 (1982).

88. Id. at 600 .

89. Id. at $609-10$.

90. Id. at 608-09.

91. Id. at 610 .

92. Id. at 606-07. Justice O'Connor concurred in the judgment; Chief Justice Burger dissented, joined by Justice Rehnquist, and Justice Stevens also dissented.

93. 464 U.S. 501, 503 (1984).

94. Id.

95. Id. at 503-04.

96. Id. at 513 . 
be articulated along with findings specific enough that a reviewing court can determine whether the closure order was properly entered.

At the same time, in Waller v. Georgia, the issue of access to suppression hearings reached the Court. ${ }^{98}$ Georgia authorities had charged several persons with racketeering, gambling, and communicating information related to gambling. ${ }^{99}$ The defendants moved to suppress certain evidence, including wiretaps. ${ }^{100}$ In response, the prosecution moved to close a hearing on the suppression motion, arguing that conducting it in the open would expose sensitive investigative information that needed to be protected. ${ }^{101}$ Despite objections from certain defendants, the trial judge ordered closure of the suppression hearing. ${ }^{102}$ The Supreme Court reversed the judge's closure order, holding that "under the Sixth Amendment any closure of a suppression hearing over the objections of the accused must meet the tests set out" in First Amendment-based precedents, such as PressEnterprise $I^{103}$

Two years later, in Press-Enterprise Co. v. Superior Court (PressEnterprise II), the Supreme Court ruled broadly in favor of access to preliminary hearings. ${ }^{104}$ California authorities had accused a nurse of murdering twelve patients by giving them high doses of a heart drug. ${ }^{105}$ A magistrate closed a preliminary hearing "because the case had attracted national publicity and 'only one side may get reported in the media." "106 The holding in Press-Enterprise II, ${ }^{107}$ however, was that the closure order was unconstitutional, because it had not met this standard:

If the interest asserted is the right of the accused to a fair trial, the preliminary hearing shall be closed only if specific findings are made demonstrating that, first, there is a substantial probability that the defendant's right to a fair trial will be prejudiced by publicity that

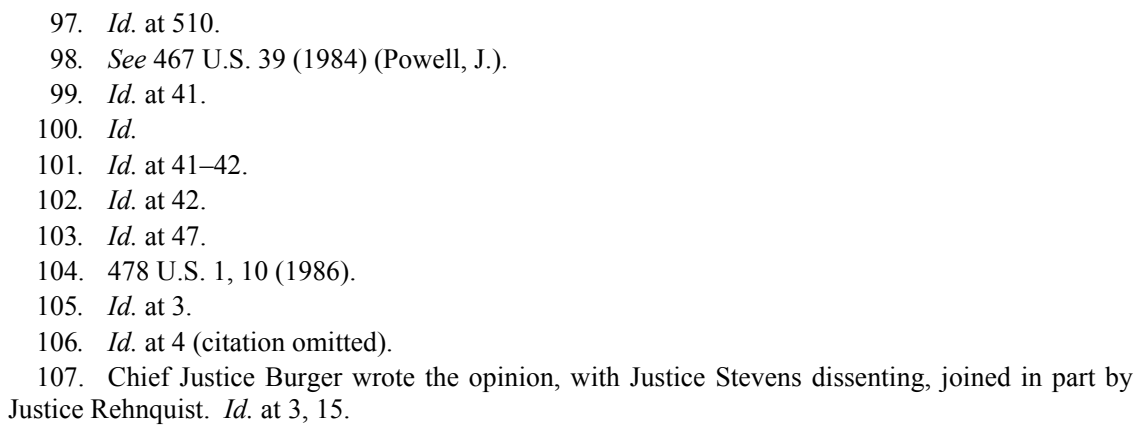


closure would prevent and, second, reasonable alternatives to closure cannot adequately protect the defendant's fair trial rights. ${ }^{108}$

\section{PREJUdicial Publicity AND FAIR TRIALS IN KANSAS}

\section{A. Claims for Mistrial}

After the Supreme Court's decisions in Estes and Sheppard, appellants in criminal cases in Kansas began to invoke the two precedents, though generally without success. The appellant in one such case had been found guilty of entering a supply company through a broken skylight and stealing wrenches from a display rack. ${ }^{109}$ The appellant claimed that he had been a victim of prejudicial publicity generated by two Hutchinson, Kansas radio stations. ${ }^{110}$ The stations' news broadcasts had included information or comments about Eldridge's marriage, performed while he was in jail, and a prior conviction in another state. $^{111}$

In State v. Eldridge, the Kansas Supreme Court ruled that it would find denial of due process if "publicity is massive, pervasive and results in influences on the jury which are disruptive and prejudicial." 112 The radio broadcasts in Eldridge's case, however, did not meet the standard. The Kansas Supreme Court said: "There is no showing in this record that a single juror was cognizant of these broadcasts or in any way influenced by them. The decorum in the courtroom appears to have been properly maintained entirely free of pervasive and disruptive influences." 113

The Kansas Supreme Court also ruled against subsequent appellants who invoked the Estes and Sheppard precedents, claiming that they were victims of prejudicial publicity and had been denied due process. ${ }^{114}$ The

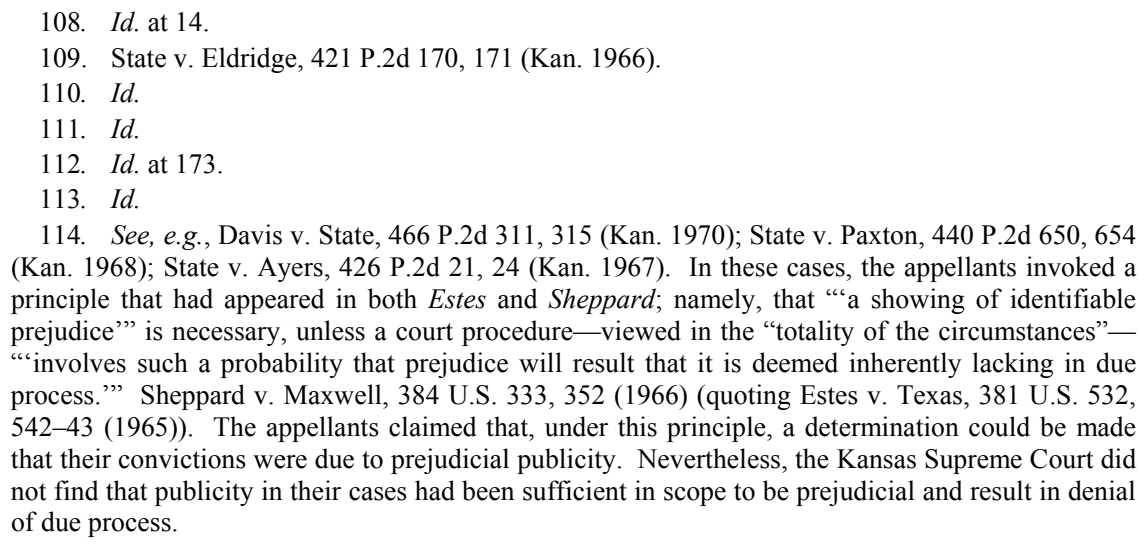
(Kan. 1968); State v. Ayers, 426 P.2d 21, 24 (Kan. 1967). In these cases, the appellants invoked a principle that had appeared in both Estes and Sheppard; namely, that " a showing of identifiable prejudice" is necessary, unless a court procedure-viewed in the "totality of the circumstances""involves such a probability that prejudice will result that it is deemed inherently lacking in due process." ' Sheppard v. Maxwell, 384 U.S. 333, 352 (1966) (quoting Estes v. Texas, 381 U.S. 532, 542-43 (1965)). The appellants claimed that, under this principle, a determination could be made that their convictions were due to prejudicial publicity. Nevertheless, the Kansas Supreme Court did not find that publicity in their cases had been sufficient in scope to be prejudicial and result in denial of due process. 
rulings tended to impose a heavy burden on defendants to show that they suffered prejudice because of publicity.

For trial judges who are concerned about the prejudicial effects of publicity before trial, the questioning of prospective jurors during voir dire is key. As the Kansas Supreme Court pointed out nearly forty years ago: "Basically, the purpose of voir dire examination is to enable parties to select jurors competent to judge and determine facts in issue without bias, prejudice or partiality." 115 The trial judge has discretion to decide the extent of voir dire examination ${ }^{116}$ and an appellate court essentially will not interfere "unless an abuse of discretion is clearly shown."

A 2006 case, State v. Hayden, ${ }^{118}$ illustrated trial judges' latitude in conducting voir dire when pre-trial publicity is an issue. The defendant in Hayden had been accused of attacking an elderly husband and wife in their home with a shovel. ${ }^{119}$ The wife died, and the defendant was convicted of second degree murder and other crimes. ${ }^{120}$ Before trial, his attorney opposed conducting a voir dire examination of the prospective jurors as a group, arguing that they " w[ould] have to be interrogated as to the nature of the publicity [to which they had been exposed].... Forthright answers would very likely contaminate the entire venire ....",121

On appeal, the defendant claimed that the trial judge had erred by disallowing voir dire examination individually of each prospective juror. ${ }^{122}$ The Kansas Supreme Court rejected the defendant's claim, ${ }^{123}$ however, noting with approval that the trial judge had cautioned the prospective jurors as a group not to give "intemperate" answers to questions during voir dire. ${ }^{124}$ The court found that "[ $\left.t\right]$ he judge asked very specific questions so that venire members did not blurt out unnecessary prejudicial information, and he dismissed jurors who said

115. State v. Guffey, 468 P.2d 254, 259 (Kan. 1970).

116. Id. (citing State v. Maxwell, 102 P.2d 109 (Kan. 1940)).

117. Id.; see also Wilson v. Sirmons, 536 F.3d 1064, 1097 (10th Cir. 2008) (citing Mu'Min v. Virginia, 500 U.S. 415, 427 (1991)) ("The trial court retains great flexibility in conducting voir dire.").

118. 130 P.3d 24 (Kan. 2006).

119. Id. at $27-28$.

120. Id.

121. $I d$. at 28 .

122. Id. at 29

123. Id. at 37. Although the appellant in State v. Hayden did not prevail in arguing that individual voir dire should have been allowed, he won reversal of his conviction on another ground. Before being retried, however, he pled guilty to second-degree murder and was sentenced to fifteen and a half years in prison, with credit for five years he had already served. See Associated Press, Olathe Man Pleads Guilty in Attack on Elderly Couple, TOPEKA CAP.-J., Oct. 13, 2006, at 5C.

124. Hayden, 130 P.3d at 37. 
they could not put what they had seen or heard in the media out of their minds to decide the case impartially." 125 The court held that in denying the defendant's request for individual voir dire, the trial judge had not abused his discretion, explaining the standard as follows:

[D]iscretion is abused when judicial action is "arbitrary, fanciful, or unreasonable," which is another way of saying that discretion is abused only when no reasonable person would take the view adopted by the trial court. If reasonable persons could differ as to the propriety of the action taken by the trial court, then it cannot be said that the trial court abused its discretion. ${ }^{126}$

Even when jurors are exposed to arguably prejudicial publicity during a trial, a defendant may have difficulty showing that a new trial is warranted. For many years, the Kansas Supreme Court has appeared reluctant to rule in favor of litigants who complain about prejudicial trial publicity. A case in point occurred in 1905 during a civil dispute in Lyon County, Kansas. ${ }^{127}$ The plaintiff had sued the defendant over a $\$ 10,000$ promissory note, and local newspapers published articles that were "distinctly unfavorable" to the plaintiff, both in style and substance. ${ }^{128}$ After a week-long trial, the jurors returned a verdict against the plaintiff, and he requested a new trial on the theory that the newspaper articles had prejudiced them against him. ${ }^{129}$ Four jurors signed affidavits saying that they had read something in the papers about the plaintiff, although eight jurors said they had not. ${ }^{130}$ The Kansas Supreme Court said that jury misconduct was not to be presumed, the plaintiff had the burden of proof on the issue of prejudice, the contents of the articles read by the four jurors were unknown, and there was "no direct evidence" that would justify setting aside the verdict. ${ }^{131}$

The spirit of the 1905 case was apparent in subsequent cases. In 1973, in Roy v. State, for example, the Kansas Supreme Court stated:

[This court] has consistently adhered to the well-settled principle applicable both to civil and criminal cases, that a juror's reading of newspaper articles pertaining to the trial is not grounds for reversal, new trial, or mistrial unless the articles are of such a character that they

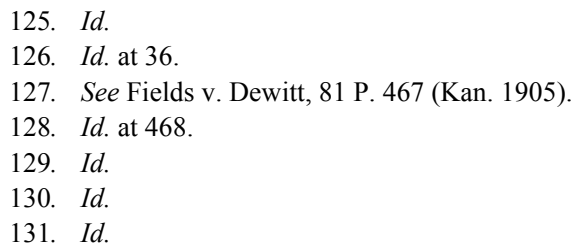


might have resulted in prejudice to the losing party. To constitute grounds for such action it must affirmatively appear that prejudice has resulted, and the party claiming prejudice has the burden of proof. ${ }^{132}$

In a 1994 case, State v. Bowen, ${ }^{133}$ the Kansas Supreme Court reviewed its position on trial publicity in some detail. The defendant in Bowen had been charged with first-degree murder and one count of aggravated battery in connection with a shooting on a Wichita street. ${ }^{134}$ On the second day of the trial, the Wichita Eagle published an article with this headline: "Witness fingers gunman/Woman defies threats to testify in friend's slaying." 135 The first paragraph said: "The murder trial of a 20year-old man who police say is a Los Angeles gang 'banger,' or hit man, opened Tuesday in Sedgwick County District Court with nervous testimony from an eyewitness who claimed she had been threatened to prevent her from showing up in court." 136 Evidence at trial included nothing about the threat that the newspaper had reported. ${ }^{137}$ In response to concern expressed by the defendant's attorney about the prejudicial effect of the article, the trial judge conducted an inquiry as follows:

THE COURT: Members of the jury, at this time I want to make an inquiry of you to each of you answer-I want you to answer the question. There was an article in the paper about this particular case. Now, did any of you read that article or see that article? If you did please raise your hand.

MR. LANGE: I saw the article.

THE COURT: You saw the article?

MR. LANGE: I realized what it was about and I didn't read it.

THE COURT: And, Mr. Patrick Robinson, you also saw it?

MR. ROBINSON: Now, I saw the headline and saw a name and then set it aside.

THE COURT: Did anyone else see the article or read any of it? I see no affirmative answers.

132. 514 P.2d 832, 834 (Kan. 1973) (citations omitted) (rejecting an appeal in a manslaughter case on prejudicial publicity and other grounds).

133. 867 P.2d 1024 (Kan. 1994).

134. Id. at 1027.

135. Id. at 1029-30 (citation omitted).

136. Id. at 1030 (citation omitted).

137. Id. 
THE COURT: On the basis of merely seeing the headline of the article, I do not see that that would in any way... influence the jury. You can't put blinders on the jurors, and, therefore, I will go ahead with the trial. Is the State ready to proceed?

The decision of the trial judge to deny a mistrial was upheld as a proper exercise of discretion. The Kansas Supreme Court pointed out that the judge initially had taken a precaution against prejudicial publicity by admonishing the jury to avoid news reports about the case. ${ }^{139}$ Moreover, the manner in which the judge polled the jury was reasonable. ${ }^{140}$ The court ultimately concluded:

The fact that a juror has read a newspaper article does not automatically constitute grounds for a mistrial. The two jurors in the instant case who saw the single article in question did not indicate that they had read it in its entirety. The content of the offending headlines is not of such a nature that prejudice should be presumed. Bowen had the burden to demonstrate that he was prejudiced. ${ }^{14}$

In a 2008 case with an ironic twist, a trial court in Johnson Countyrather than the media-was the source of allegedly prejudicial publicity. ${ }^{142}$ An insurance agent had been accused of forgery. ${ }^{143}$ During his trial, the court posted the following information on a website about the history of the case: "“06/01/2006 FILE STAMP 6/1/2006, MOTION TO ALLOW EVIDENCE OF DEFENDANT'S ADMISSION OF A [sic] GAMBLING AND MONEY PROBLEMS." "144 The entry referred to evidence that the judge ultimately refused to admit "because it was irrelevant and prejudicial," but the defendant argued that "“jurors had easy access to this statement via the internet from the privacy of their own homes." 145 After the defendant was convicted, he appealed on grounds that included prejudicial publicity, and he requested a mistrial. ${ }^{146}$ His appeal was rejected, however. ${ }^{147}$ The Kansas Court of Appeals noted

\footnotetext{
138. Id.

139. Id. at $1030-31$.

140. Id. at 1031. The court indicated that the trial judge took some risk in polling the jurors about their exposure to publicity, indicating that such polling was a disfavored practice. The concern was that questioning jurors about publicity could lead them to be prejudiced.

141. Id. (citations omitted).

142. State v. Auch, 185 P.3d 935, 944 (Kan. Ct. App. 2008).

143. Id. at 938 .

144. Id. at 945

145. Id.

146. Id. at 944 .

147. Id. at 946 .
} 
that the declaration of a mistrial is a matter of discretion for the trial judge, and an appellate court will not reverse the judge's decision "unless an abuse of discretion is clearly shown" and the defendant proves that he or she was "substantially prejudiced." 148 Regarding mistrials generally, Kansas law

gives the trial court the discretion to grant a mistrial when it finds that termination is necessary because "[p]rejudicial conduct, in or outside the courtroom, makes it impossible to proceed with the trial without injustice to either the defendant or the prosecution." A mistrial will not be granted ... unless the rights of either the defendant or the State have been substantially prejudiced. ${ }^{149}$

The Kansas Court of Appeals held that the trial judge's decision not to grant a mistrial was a reasonable exercise of discretion. ${ }^{150}$ The record of the case included no indication that any juror saw the court's website entry or, if any did see it, that the entry caused them to be prejudiced against the defendant. ${ }^{151}$

The outcome of this case is consistent with the trend in Kansas. For criminal defendants who challenge their convictions on the ground of prejudicial publicity, the burden of proof is high. Trial judges appear to run a minimal risk of being reversed when they deny a motion for a mistrial by one who claims to have been a victim of prejudicial publicity. A recent survey identified 105 Kansas cases in which prejudicial publicity was a ground for appeal, but a preliminary analysis of the cases indicated that only one conviction was reversed due to publicity. ${ }^{152}$

148. Id. at 944 (citing State v. Dixon, 112 P.3d 883 (Kan. 2005)).

149. Id. at 945 (citing KAN. STAT. ANN. § 22-3423(1)(c) (2007) (prescribing conditions under which a trial may be terminated and a mistrial ordered)).

150. See id. at 946 ("Because the record in this case fails to indicate that prejudice resulted to Auch from the case history posting, he is not entitled to a mistrial in this case.").

151. Id.

152. The survey, initiated by the author and conducted with the help of an assistant in December 2008 and January 2009, consisted of an electronic database search. The objective was to identify cases in which Kansas appellate courts had reversed a criminal conviction on the ground of prejudicial publicity. Terms used for the search included "publicity," "trial," "reverse," and "prejudice." Although further analysis of the results is pending, State v. McDonald, 565 P.2d 267 (Kan. 1977), is the only case found thus far, out of 105, in which a claim of prejudicial publicity was upheld. In that case, the Kansas Supreme Court ruled that the trial judge wrongly denied a defense motion to examine jurors regarding circulation of an inflammatory pamphlet about the defendant. 


\section{B. Gag Orders}

\section{Against the Media}

Soon after the United States Supreme Court decided Nebraska Press in 1976, the Kansas Supreme Court had occasion to follow the decision in a controversy that centered on the Board of Public Utilities of Kansas City, Kansas. A trial court had decided to oust two of the board's members on grounds that they had mishandled certain financial matters. On appeal, the ousted board members claimed that the trial court should have prohibited the media from reporting witnesses' testimony. In State ex rel. Tomasic v. Cahill, however, the Kansas Supreme Court upheld the ouster and said that, under Nebraska Press, the media were "quite properly permitted to report proceedings which took place in open court. The need for the public to know what is going on in an ouster proceeding is substantial, and certainly outweighs the remote possibility of prejudice to parties in this civil proceeding." 153

Four years later, the court rejected an appeal by a convicted murderer who argued that a gag order should have been issued against the media in his case. ${ }^{154}$ The trial judge's decision not to issue such a restraint was upheld, because no prejudice was alleged or shown. ${ }^{155}$

The Kansas Supreme Court thoroughly affirmed its opposition to prior restraints in a case that originated in 1993 in Atchison, Kansas. ${ }^{156}$ A newspaper reporter was attending a pre-trial criminal hearing in a local courtroom. ${ }^{157}$ The hearing was open to the public, ${ }^{158}$ and the reporter's presence was ordinary. Nothing portended the confrontation that was about to occur.

As the reporter watched, the judge considered a defense motion to suppress certain evidence. ${ }^{159}$ The defense attorney argued that the prosecution should be barred from using or discussing the defendant's criminal record or outstanding arrest warrants. ${ }^{160}$ After granting the motion, the judge asked whether any other matter needed attention. ${ }^{161}$ The attorney then pointed out the presence of the reporter, who worked

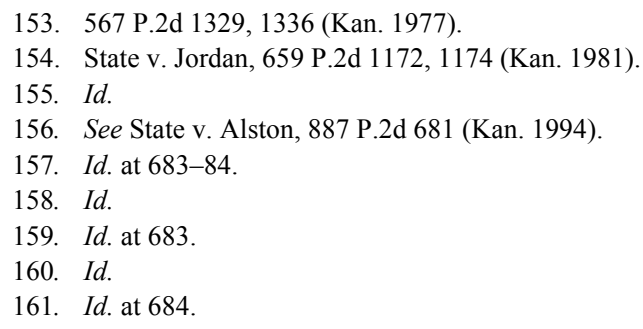


for the Atchison Daily Globe, and expressed concern that the newspaper might publish a report about the hearing. ${ }^{162}$ The judge immediately ordered the reporter to publish neither the defendant's criminal history nor even the existence of the judge's order itself. ${ }^{163}$

The Globe, however, defied the order, publishing a report about what had happened in the courtroom. As a headline put it: "[Judge] imposes gag order on Globe; Tells newspaper not to report order because it might prejudice... jurors." 164 Another headline said: "Globe publisher says public has right to know about case; Judge's gag order called unwarranted." 165 The report began: "The Atchison Daily Globe defied a gag order placed on the newspaper by [the judge] because the newspaper felt public interest outweighed the reasons for the order...." ${ }^{\prime 66}$ The report quoted the publisher as saying: "We respect the judicial system and [the judge] and the right for everyone to have a fair trial, but we also believe, based on the First Amendment, we have a right to report the news. In this particular place, a gag order on the Globe is not a necessary thing." 167

For its defiance of the gag order, the Globe received a contempt citation, but the newspaper successfully appealed. ${ }^{168}$ In State v. Alston, the Kansas Supreme Court reversed the gag order and the contempt citation. ${ }^{169}$ The court recognized that "those who see and hear what transpired in an open courtroom can report it with impunity," and "once a public hearing has been held, what transpired there could not be subject to prior restraint."170 The court followed the United States Supreme Court's rejection of a gag order in Nebraska Press ${ }^{171}$ as an unconstitutional prior restraint. ${ }^{172}$

At the same time, the Kansas Supreme Court embraced a line of precedent that preserved the media's defense against "transparently invalid" gag orders. ${ }^{173}$ The Globe was subject to the general rule that

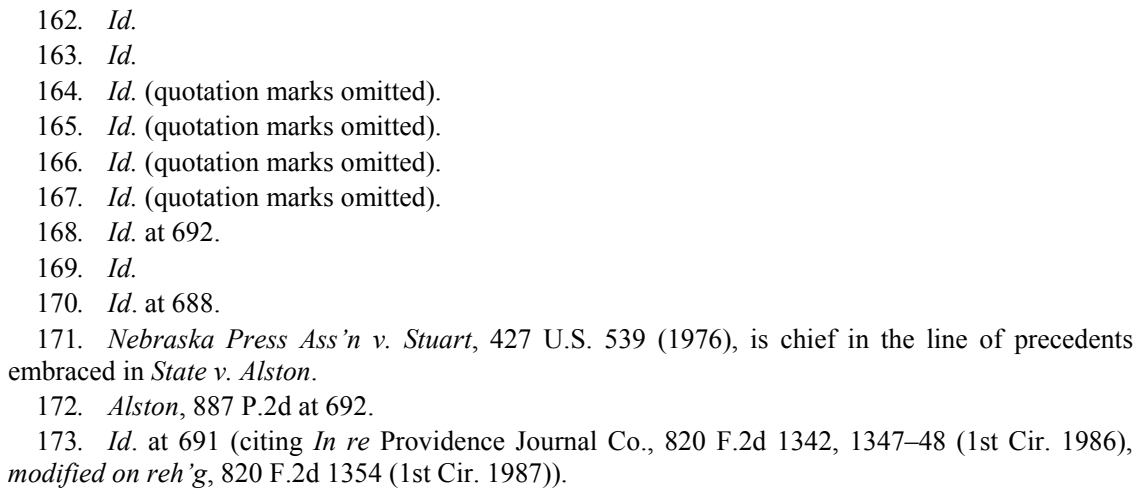


persons must obey a judicial order even if they believe it is unconstitutional. ${ }^{174}$ Even if they challenge the constitutionality of the order on appeal, they must continue to obey it while awaiting a decision. ${ }^{175}$ If they disobey the order and are cited for contempt, they are barred from collaterally attacking the constitutionality of the order during the contempt proceeding. ${ }^{176}$ The collateral bar rule has been considered necessary for the "efficient and orderly administration of justice."

In Alston, however, the Kansas Supreme Court found that the Globe was not bound by the collateral bar rule when it disobeyed a gag order and published news about a pre-trial criminal hearing. ${ }^{178}$ The collateral bar rule does not apply when a judicial order is "transparently invalid," the court said, explaining:

In this case, the $\ldots$ order was transparently unconstitutional. The trial court failed to make the requisite Nebraska Press findings. The [newspaper had based its news report on information that was available from] the court's records and in open court prior to the gag order. The order was issued without a full and fair hearing with all the attendant procedural protection.

The court found that the Globe had disobeyed the gag order in good faith. ${ }^{180}$ "In the course of two hours, the Globe received notice of the order, contacted the judge, and attempted to contact its attorney and the attorney for the Kansas Press Association ...."181 Relief through the judicial system, however, was not available before the newspaper's publication deadline. ${ }^{182}$ According to the court, "[o]nly where timely access to an appellate court is not available can the newspaper publish and then challenge the constitutionality of the order in contempt proceedings." 183 Alston established that a newspaper "seeking to challenge an order it deems transparently unconstitutional must concern itself with establishing a record of its good faith effort." 184

\footnotetext{
174. Id. at 690 .

175. See id.

176. See id.

177. Id.

178. Id. at 691 .

179. Id

180. Id. at 691-92.

181. Id. at 691 .

182. Id. at 692 .

183. Id. at 691 .

184. Id.
} 


\section{Against Trial Participants}

To judges, issuing gag orders against trial participants - those from whom journalists seek newsworthy information and comment-has appeared to be a reasonable and practical alternative to imposing a prior restraint on the media. Lucy Dalglish, director of the Reporters Committee for Freedom of the Press in Arlington, Virginia, has noted that restraints on trial participants' speech have increased. ${ }^{185}$ As she put it: "“Are we seeing more gag orders? Absolutely. In general they are a tool that was used by courts depending on the jurisdiction, but once they catch on they spread like wildfire." "186

Gag orders against trial participants generally have not been as controversial in Kansas as in some other jurisdictions. U.S. District Judge Sam A. Crow, however, was the central figure in two noteworthy cases that involved gag orders in Topeka, Kansas. In United States v. Walker, a defendant had been charged with cocaine possession, and he requested an "order directing the United States Attorney, his assistants, law enforcement officers, and any other persons associated with the above-referenced case to refrain from making any extrajudicial statements about this case."187 The defendant said a gag was necessary, because publicity "indicating that he was the leader of the Topeka Black Gangster Disciples gang jeopardized his ability to obtain a fair trial."188 Judge Crow denied the request, however, saying:

Though the speech of an attorney participating in judicial proceedings may be subjected to greater limitations than could constitutionally be imposed on other citizens or on the press, the limitations on attorney speech should be no broader than necessary to protect the integrity of the judicial system and the defendant's right to a fair trial. This Court has stated that before a district court issues a blanket prior restraint, it must, inter alia, "explore whether other available remedies would effectively mitigate the prejudicial publicity," and consider "the effectiveness of the order in question" to ensure an impartial jury.

185. Jason Dearen, Gag Orders Becoming Court Trend, The OAKLAND TribunE, Nov. 27, 2005 , at A1.

186. Id.

187. 890 F. Supp. 954,956 (D. Kan. 1995).

188. Id. 
Less restrictive alternatives to an injunction against speech include such possibilities as a change of venue, trial postponement, a searching voir dire, emphatic jury instructions, and sequestration of jurors. ${ }^{189}$

Judge Crow concluded that a fair trial could be achieved without a gag order. ${ }^{190} \mathrm{He}$ favored such less restrictive alternatives as "a probing voir dire and the use of proper jury instructions."191

In a high-profile civil case in 1998, however, Judge Crow imposed a gag order with unusually broad scope against trial participants. He was presiding over Koch v. Koch Industries, Inc., a complex case that had begun in 1985. ${ }^{192}$ The plaintiffs were stockholders who claimed that they had been victims of misrepresentation by principals in the second-largest, privately held corporation in the United States. ${ }^{193}$ As the time for trial drew near, Judge Crow issued a gag order to minimize publicity about the case. ${ }^{194}$ Through his order, he prevented any parties, or their agents or representatives, "from contacting or polling, for any purpose, any person listed as a prospective juror"; precluded "all parties, counsel and witnesses from making extrajudicial statements to the news media"; forbade any party, or any business, association, entity or commission controlled by a party, from advertising through newspapers, radio, or television in the seventeen counties within the court's jurisdiction; and required prospective jurors to make "every effort" to avoid reading newspaper or magazine articles, listening to any radio programs, or viewing any television programs that could relate to the case. ${ }^{195}$

Before issuing his gag order, Judge Crow did not hold a hearing specifically to give news organizations an opportunity to register objections. ${ }^{196}$ He then denied a motion by the media to intervene and object after he issued the gag order. ${ }^{197}$ Although he acknowledged that a judge should not impose a prior restraint on speech without first conducting a hearing, he characterized Koch as an "atypical" case, and

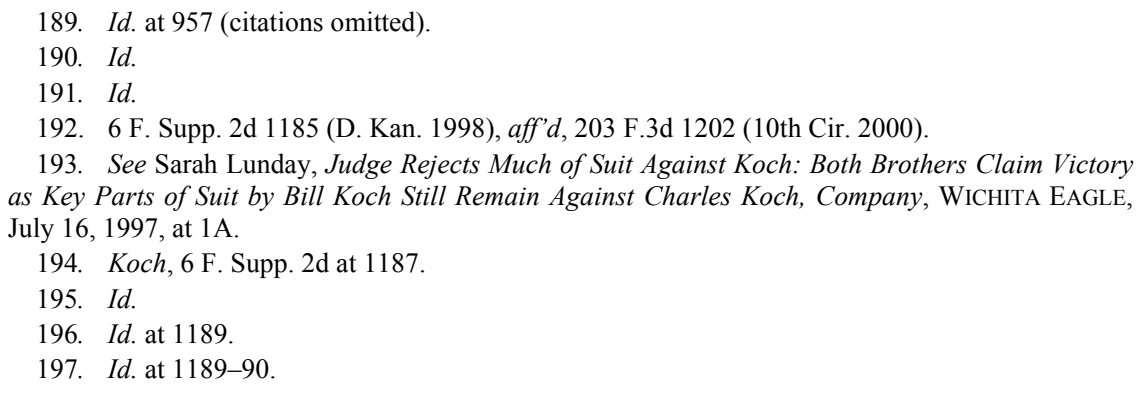


said he had raised the subject of the gag order in open court during a status conference. ${ }^{198}$ He further stated:

[A]ll parties agreed that the court had provided the relief that they had requested. Lead counsel for both sides expressed great enthusiasm for the order entered by the court, as the news media had previously been playing one side off the other in an effort to pry information from the litigants or their counsel. In short, all litigants eschewed any desire to talk with the news media about this case. ${ }^{199}$

In light of First Amendment values and the presumption of openness established by the United States Supreme Court, trial judges are expected to follow procedures with care before issuing gag orders against trial participants. For example, media in Ohio once objected to a gag order that a trial judge had issued without prior notice, without evidence, and without a hearing. ${ }^{200}$ The order, issued before a murder trial, forbade "prosecutor's staff and personnel, including the prosecutor, all defense counsel staff and personnel, including both primary defense counsel, and all law enforcement agencies and personnel" from making "any extra judicial statement by means of public communication other than 'no comment." 201 The Ohio Supreme Court invalidated the gag order, saying:

[W]e hold that a gag order cannot issue unless "specific, on the record findings" are made demonstrating that a gag order is " "essential to preserve higher values and is narrowly tailored to serve that interest." If the interest asserted is the right of the accused to a fair trial, the gag order may issue only if "specific findings are made demonstrating that, first, there is a substantial probability that the defendant's right to a fair trial will be prejudiced by publicity that... [the gag order] would prevent and, second, reasonable alternatives ... cannot adequately protect the defendant's fair trial rights...." Moreover, "representatives of the press and general public "must be given an opportunity to be heard on the question ....",202

Federal courts have imposed gag orders against attorneys and other trial participants under various standards. In a 1969 case, the Tenth Circuit held that a gag order constitutionally may be "based on a

198. Id.

199. Id. at 1190.

200. State ex rel. Nat'l Broad. Co. v. Court of Common Pleas, 556 N.E.2d 1120, 1123-25 (Ohio 1990), overruled on other grounds by State v. Schlee, 882 N.E.2d 431 (Ohio 2008).

201. Id. at 1123.

202. Id. at 1125 (citations omitted). 
'reasonable likelihood' of prejudicial news which would make difficult the impaneling of an impartial jury and tend to prevent a fair trial."203 Some other circuits are more restrictive, permitting a gag order against trial participants only if there is a "clear and present danger" or a "serious and imminent threat" to fairness of a trial. ${ }^{204}$

Despite varying standards, the First Amendment can prevent sweeping, judicially imposed restraints on comments by trial participants. For example, a trial judge may try to bar journalists from interviewing jurors after a trial has ended. However, as one court concluded, "restrictions on post-trial interviews must reflect an impending threat of jury harassment rather than a generalized misgiving about the wisdom of such interviews." 205

The First Amendment may protect pre-trial participants as well. When a Florida newspaper reporter was called before a grand jury, a state statute generally prohibited grand jury witnesses from ever disclosing their testimony. ${ }^{206}$ The United States Supreme Court, however, held that "insofar as the Florida law prohibits a grand jury witness from disclosing his own testimony after the term of the grand jury has ended, it violates the First Amendment to the United States Constitution." 207

First Amendment protection may not be available, however, to witnesses who seek to disclose information they gained about grand jury proceedings in the course of testifying. In Hoffmann-Pugh v. Keenan, the Tenth Circuit supported enforcement of grand jury secrecy rules

203. United States v. Tijerina, 412 F.2d 661, 666 (10th Cir. 1969). This case arose when authorities accused five individuals of assaulting U.S. forest rangers and other crimes. United States v. Tijerina, 407 F.2d 349, 351 (10th Cir. 1969). The judge imposed the gag order against the defendants, as well as attorneys and witnesses for both sides. Tijerina, 412 F.2d at 663 . The defendants were convicted, and two of them challenged the gag order as violative of the First Amendment. Id. at 666 .

204. See United States v. Brown, 218 F.3d 415, 426-28 (5th Cir. 2000) (holding that a district court may "impose an appropriate gag order on parties and/or their lawyers if it determines that extrajudicial commentary by those individuals would present a 'substantial likelihood' of prejudicing the court's ability to conduct a fair trial"). The Fifth Circuit reviewed the lack of consensus on standards for gag orders against trial participants, noting that the standard embraced in the Fourth Circuit is like that in the Tenth Circuit and that "more stringent tests, requiring either a showing of 'clear and present danger' or 'serious and imminent threat' of prejudicing a fair trial" are required in the Sixth, Seventh, and Ninth Circuits. Id. at 427. The Fifth Circuit requires "a lesser showing of potential prejudice": either a "substantial likelihood" or possibly "merely a "reasonable likelihood" that extrajudicial comments by participants, including lawyers and parties, "will undermine a fair trial." Id. at 428. It may then "impose a gag order on the participants, as long as the order is also narrowly tailored and the least restrictive means available." Id.

205. United States v. Antar, 38 F.3d 1348, 1364 (3d Cir. 1994).

206. Butterworth v. Smith, 494 U.S. 624, 626 (1990).

207. Id. 
against an aspiring author. ${ }^{208}$ The plaintiff was a housekeeper for the parents of JonBenet Ramsey, the child whose 1996 murder in Colorado attracted extraordinary national attention. ${ }^{209}$ After the housekeeper became involved in a grand jury investigation of the murder, she planned to write a book about her experience. ${ }^{210}$ Colorado grand jury secrecy rules did not prevent the housekeeper from disclosing information she possessed before her grand jury appearance. ${ }^{211}$ The secrecy rules prohibited her, however, from disclosing matters that she had "learned from her participation in the grand jury process, at least so long as the potential remains for another grand jury to be called to investigate an unsolved murder." 212

\section{The Presumption of Openness}

In a 1981 case, the Kansas Supreme Court faced the question of whether a trial judge constitutionally could close a criminal proceeding. The case, Kansas City Star Co. v. Fossey, arose when a juvenile who had been certified as an adult faced trial for murdering his thirteen-year-old stepbrother in Miami County, Kansas. ${ }^{213}$ After selection of the jury, the trial judge, Leighton A. Fossey, acted on his own motion to schedule a hearing on whether incriminating statements that the defendant had made to the police were involuntary and should be suppressed. ${ }^{214}$ When Judge Fossey indicated in open court that he would exclude the press and public from the suppression hearing, a Kansas City Times reporter objected by reading a prepared statement. ${ }^{215}$ She requested that the judge hold a hearing on whether to close the courtroom. ${ }^{216}$ Judge Fossey, however, rejected the request, closed the courtroom and conducted the suppression hearing. ${ }^{217}$ He ruled that the defendant's incriminating statements would be admitted into evidence at the trial and that he would permit reporters covering the trial to read the defendant's statements only after they were introduced into evidence. ${ }^{218}$ Judge Fossey's reasoning

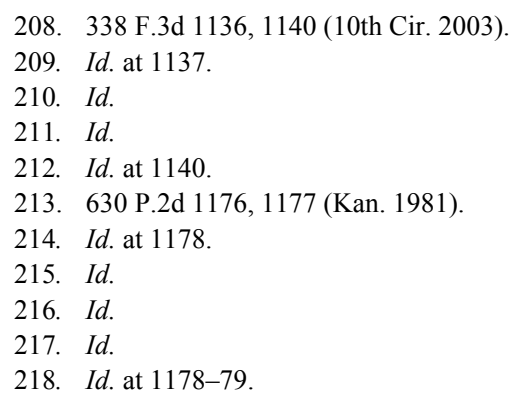


was that he "did not want the jury exposed to any more publicity than necessary." 219

The Kansas City Star Company, which published the Kansas City Times, responded by filing a motion to intervene. ${ }^{220}$ The Star asked that the closure order be vacated and also requested a transcript of the suppression hearing. ${ }^{221}$ Judge Fossey denied the motion to vacate, yet ruled that the Star could receive a copy of the transcript from a court reporter. ${ }^{222}$ The murder trial went forward and resulted in a guilty verdict, but the Star filed a mandamus action with the Kansas Supreme Court, challenging Judge Fossey's closure of the suppression hearing. ${ }^{223}$

Even though the hearing had occurred after the jury was impaneled, the Kansas Supreme Court chose to view it as a pre-trial proceeding and consequently found Richmond Newspapers inapplicable. ${ }^{24}$ Instead, the court relied on DePasquale and upheld the closure of the hearing, saying such action is justified when "necessary to insure a fair trial for the defendant." 225

As for the future, however, the court announced that a trial judge may close a pre-trial criminal proceeding " "only if (i) the dissemination of information from the pretrial proceeding and its record would create a clear and present danger to the fairness of the trial, and (ii) the prejudicial effect of such information on trial fairness cannot be avoided by any reasonable alternative means.",226

The court derived its two-part test from standards for the conduct of criminal proceedings that the ABA approved in 1978, which replaced the standards the organization had first published in $1968 .^{227}$ The 1978 standards were more favorable to First Amendment interests than the original and tended to be consistent with the United States Supreme Court's holding in Richmond Newspapers. The standards called for "a strong presumption in favor of open judicial proceedings." 228 The standards did not limit the general principle of openness to pre-trial proceedings; rather, openness extended "to every phase of judicial

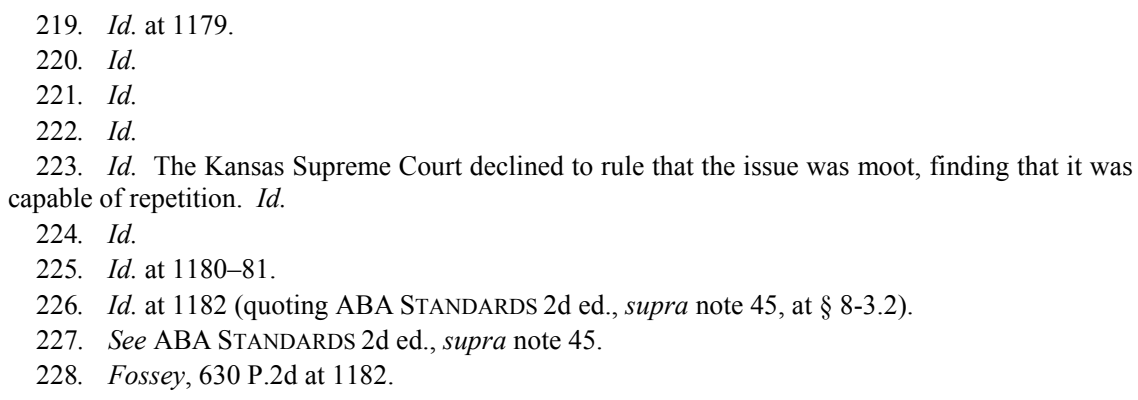


proceedings in a criminal case." ${ }^{229}$ As the Kansas Supreme Court acknowledged in Fossey:

In recent years, there has been a great deal of discussion on the subject of "fair trial and free press" and the right of the public and news media to attend court proceedings. There is almost universal agreement among the courts and writers who have considered the issue that access to court proceedings should be limited only in exceptional circumstances. It has been said that the reason for requiring all court proceedings to be open, except where extraordinary reasons for closure are present, ... is to enhance the public trust and confidence in the judicial process and to insulate the process against attempts to use the courts as tools for persecution. ${ }^{230}$

The public interest in access to courts, according to the Kansas Supreme Court, "'is at least as strong as the first amendment policy against prior restraints.",231 Before restricting access, a trial judge must conduct a hearing and

make findings and state for the record the evidence upon which the court relied and the factors which the court considered in arriving at its decision. Such a procedure will protect both the right of the defendant to a fair trial and the right of the public and news media to have access to court proceedings. ${ }^{23}$

The Fossey decision explicitly applied the presumption of openness to any pre-trial proceeding, including a bail hearing. ${ }^{233}$ In addition, because of Fossey's implicit endorsement of court access generally and because of other precedents, most other proceedings - ranging from voir dire $^{234}$ to expungement hearings ${ }^{235}$ - are presumptively open in Kansas.

In 2005, the Kansas Supreme Court again reviewed the limitations on judges' authority to close court proceedings. A defendant had been convicted of two murders and other charges in connection with an

235. Stephens v. Van Arsdale, 608 P.2d 972, 985 (Kan. 1980) ("The public or press are free to attend the original trial or the sentencing hearing or any post-judgment hearings or the expungement proceeding itself.").
} 
explosion and fire at an apartment building. ${ }^{236}$ The trial judge closed the courtroom to the media and spectators during an announcement of the jury's verdict. ${ }^{237}$ The purpose of the closure was to prevent news of the verdict from reaching jurors who had been selected to sit in a pending, related criminal case. ${ }^{238}$

In State v. Dixon, the Kansas Supreme Court indicated that the process by which the trial judge had decided to close the proceeding complied with Press-Enterprise I, observing that "the trial court went to great lengths to articulate the interest to be served by closure as well as its findings on reasonable alternative means." 239 Nevertheless, after taking Waller into account, the court concluded that closure of court proceedings must be consistent with both the First and Sixth amendments. ${ }^{240}$ As was explained in Dixon:

Here, the trial court considered the advocated interests and the alternatives. The trial court exercised care in striking a balance of those interests. But the court's decision was made in response to intervention by area newspapers, whose interests were the First Amendment interests of media freedom. Although defense counsel made a simple statement of objection to closing the courtroom, the Sixth Amendment interest in a public trial seems not to have been pressed. [I]t was [the defendant's] right to a public trial that is at issue here. ${ }^{241}$

The closure, the court held, "was inconsistent with the substantial right of Dixon to a public trial and not harmless error." 242

Access to post-trial proceedings, including plea hearings, generally has been presumed throughout the United States in light of such precedents as Press-Enterprise II. For example, in 1986, in In re Washington Post Co., the Fourth Circuit addressed whether the media and the public have a First Amendment right of access to hearings on sentencing, as well as pleas. ${ }^{243}$ The conclusion was in favor of openness:

Sentencing can occur before the termination of the trial proceeding, and, even if it occurs in a separate hearing, it clearly amounts to the culmination of the trial. Moreover, even if plea hearings and sentencing hearings are not considered a part of the trial itself, they are

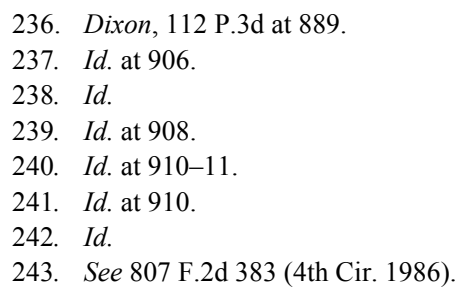


surely as much an integral part of a criminal prosecution as are preliminary probable-cause hearings, suppression hearings, or bail hearings, all of which have been held to be subject to the public's First Amendment right of access.

In addition, historical and functional considerations weigh in favor of finding a First Amendment right of access here. Sentencings have historically been open to the public; while plea hearings do not have the same long tradition, they are typically held in open court. As to both, public access serves the important function of discouraging either the prosecutor or the court from engaging in arbitrary or wrongful conduct. The presence of the public operates to check any temptation that might be felt by either the prosecutor or the court to obtain a guilty plea by coercion or trick, or to seek or impose an arbitrary or disproportionate sentence. $^{244}$

\section{Juvenile Court Proceedings}

1. Kansas Juvenile Justice

Access to juvenile court proceedings is governed by different standards, although they may not be as restrictive as one may expect. A revised Kansas juvenile code provides that, in general, "[a]ll hearings shall be open to the public ...."245 A hearing may be closed only if a judge determines that opening it "is not in the best interests of the victim or of any juvenile who at the time of the alleged offense was less than 16 years of age. $" 246$

In an interpretation of a previous version of the juvenile code, the Kansas Supreme Court distinguished between adjudicatory and detention hearings, and upheld closure of the latter kind of hearing. ${ }^{247}$ Under the revised juvenile code, however, the rule in favor of openness applies to "detention, first appearance, adjudicatory, sentencing and all other" juvenile hearings. ${ }^{248}$

In a 2008 case, the Kansas Supreme Court observed that the Legislature generally had "eliminated the presumption of confidentiality"

\footnotetext{
244. Id. at 389 .

245. Kan. StAT. AnN. § 38-2353(a) (Supp. 2008).

246. Id.

247. See Stauffer Commc'ns, Inc. v. Mitchell, 789 P.2d 1153, 1157 (Kan. 1990).

248. § 38-2353(c). If a hearing is open, the court may still order that witnesses be sequestered. Id. If a hearing is closed, persons who may be present are limited to the juvenile, the juvenile's parents, attorneys for parties, officers of the court, the witness testifying, and the victim or the victim's family. Id. at $\S 38-2353$ (b). Others may be present by agreement of the parties, unless there is a risk of disruption to the proceedings. $I d$.
} 
for juvenile hearings, and also acknowledged various ways in which juvenile records have been opened. ${ }^{249}$ Under the revised juvenile code, the official file in a juvenile case is open, with an exception for juveniles under the age of fourteen if a judge finds that closure is in their best interests. ${ }^{250}$ Also, law enforcement records and municipal court records for juveniles age fourteen and over are open on the same terms as records for adults. ${ }^{251}$ Confidentiality applies only to the law enforcement and municipal records of juveniles under the age of fourteen. ${ }^{252}$

The revised juvenile code makes clear that a judge may close a hearing only after he or she "determines" that an open hearing would not be in the best interest of a juvenile or victim who was under sixteen years of age at the time of the offense. ${ }^{253}$ Under federal and Kansas precedents, a presumption of openness generally may be overcome only if a judge formally takes into account evidence for or against closure from interested parties and makes specific findings that can be reviewed on appeal. As the United States Supreme Court has held, closure must be based on "findings specific enough that a reviewing court can determine whether the closure order was properly entered."25

In interpreting past versions of the Kansas juvenile code, state appellate courts have considered the conditions under which findings by a judge are sufficiently specific. For example, in Pauley v. Gross, a juvenile defendant appealed an order that he be detained without bail after arrest. ${ }^{255}$ The reviewing court approvingly noted that the order had been issued by a judge who, "after notice and hearing, made specific findings including the essential ones." 256 In In re Reed, a mother challenged a judge's finding that she was "unfit" as a parent. ${ }^{257}$ The reviewing court said "substantial competent evidence" was necessary to support such a finding ${ }^{258}$ and held that a hearing in the lower court had been "rather informally" conducted and was inadequate. ${ }^{259}$

249. In re L.M., 186 P.3d 164, 170 (Kan. 2008) (citing § 38-2353).

250. Id. (citing $\S 38-2309(\mathrm{~b})$ ).

251. Id. (citing § 38-2310(c)).

252. Id. (citing $\S 38-2310$ (a)).

253. §38-2353(a).

254. Press-Enterprise I, 464 U.S. 501, 510 (1984).

255. 574 P.2d 234, 235 (Kan. Ct. App. 1977).

256. Id. at 240 .

257. 663 P.2d 675, 675 (Kan. Ct. App. 1983).

258. Id. at 678 .

259. Id. at 680 . 


\section{Federal Juvenile Delinquency Act}

Case-by-case decisions may be made under federal law on whether juvenile proceedings should be open or closed. The Third Circuit set a significant precedent in deciding whether proceedings should be open under the federal Juvenile Delinquency Act. ${ }^{260}$ The issue arose after federal authorities took action in the early 1990s against juveniles who had been arrested in connection with gang-related crimes in Pennsylvania. $^{261}$ The media requested access, and the Third Circuit decided that the delinquency act does not mandate closure of proceedings. $^{262}$ Holding that district judges could open or close proceedings on a case-by-case basis, the Third Circuit said:

We, like the government, recognize the need to avoid embarrassing and humiliating juveniles, to obtain evidence about delicate matters, and not to affect the rehabilitation of juveniles adversely. We are not convinced, however, that Congress found across-the-board closure of juvenile proceedings necessary to achieve these goals. Rather, we think Congress left the delicate task of weighing the interests of the juvenile and the public to the informed discretion of the district judge in each case. District judges are experienced at striking this kind of delicate balance in the first instance in the context of common law and other First Amendment access cases. ${ }^{263}$

\section{E. Closed Criminal Proceedings}

In various jurisdictions across the United States, the media have unsuccessfully sought access to various criminal proceedings, including grand jury deliberations.

\section{Grand Juries}

In Kansas, media access to grand juries has not surfaced as a controversial issue in the state's courts. Because of the value historically placed on the secrecy of grand juries, however, courts elsewhere have denied access to grand jury deliberations. For example, newspapers were prevented from gaining access to a grand jury investigation of the

260. See United States v. A.D., 28 F.3d 1353 (3d Cir. 1994) (interpreting 18 U.S.C. $\S \S 5031-$ $5042(2006))$.

261. Id. at 1355 .

262. Id. at 1359 .

263. Id. at 1361. 
University of Florida Athletic Program in $1988 .{ }^{264}$ The Eleventh Circuit said that opening the grand jury investigation to public view would frustrate it, in "direct contrast to the advantages public access provides" to criminal trials. ${ }^{265}$

When considering the conditions under which courts may provide information about grand jury investigations to civil litigants, the United States Supreme Court in 1979 reviewed the reasons for grand jury secrecy. ${ }^{266}$ Without secrecy, witnesses would hesitate to testify when subpoenaed and would flee or, upon becoming known, be subject to undue influence. ${ }^{267}$ Other reasons cited for keeping grand jury deliberations secret included preventing public embarrassment of persons who are accused and investigated but not indicted. ${ }^{268}$

\section{Inquisitions}

In Kansas, the attorney general's office and county and district attorneys may conduct inquisitions to investigate "any alleged violation of the laws." ${ }^{269}$ The purpose of an inquisition may be either to determine probable cause for a criminal prosecution or to gain sworn testimony following an indictment. ${ }^{270}$ An inquisition, according to the Kansas Supreme Court, is like a "one-person grand jury" and may be closed. ${ }^{271}$

\section{Bench Conferences}

Typically, media can do no more than observe when attorneys for the prosecution and defense confer privately with a judge at the bench or in chambers. Even if such a conference may be newsworthy, reporters likely will be unsuccessful if they seek access, as was indicated in a 1990 federal case in Georgia. In that case, United States v. Moody, reporters attended a hearing to determine whether a couple who were charged with

\footnotetext{
264. In re Subpoena to Testify Before Grand Jury Directed to Custodian of Records, 864 F.2d 1559,1561 (11th Cir. 1989).

265. Id. at 1562 .

266. Douglas Oil Co. v. Petrol Stops Nw., 441 U.S. 211, 218-19 (1979).

267. Id. at 219 .

268. Id.

269. Kan. Stat. AnN. § 22-3101(1) (2007); State v. Cathey, 741 P.2d 738, 744 (Kan. 1987).

270. In re T.H., 932 P.2d 1023, 1027 (Kan. Ct. App. 1997). The Kansas Court of Appeals held that an inquisition was properly closed to the public because it "dealt with confidential and family matters." Id. at 1033.

271. Cathey, 741 P.2d at 744 .
} 
obstruction of justice should be detained or released on bond. ${ }^{272}$ The couple had allegedly arranged for false testimony to be given in connection with a 1972 case involving a pipe bomb. ${ }^{273}$ After the detention hearing, the judge called on the attorneys to meet with him in chambers. ${ }^{274}$ The judge planned to hear defense objections to a prosecution plan to show that the couple were linked to two fatal mail bombings in $1989 .{ }^{275}$ When reporters made a request for access to the conference, the judge denied it. ${ }^{276}$ He said that his meeting with counsel in chambers did not meet the conditions for openness that the United States Supreme Court set in Press-Enterprise II. ${ }^{277}$ Such a conference, he said, has not been open historically, and opening it would not have a positive effect, particularly when doing so would result in publicity about inadmissible evidence. ${ }^{278}$ Even so, the media occasionally have pressed with some success for access to bench or sidebar conferences or other proceedings conducted out of the presence of the jury. ${ }^{279}$

\section{Jury Deliberations}

In the early 1930s, the United States Supreme Court reviewed why jury deliberations have historically been secret. In Clark v. United States, a member of a jury in a criminal case had been found in contempt, because she had falsely represented her qualifications for jury service. ${ }^{280}$ On appeal, she objected that her contempt conviction had been based in part on testimony by other jurors about her conduct during the jury's deliberations. ${ }^{281}$ She argued that the other jurors' testimony should not have been allowed, because the jury's deliberations were privileged and

272. 746 F. Supp. 1090, 1091 (M.D. Ga. 1990).

273. Gail Epstein, Judge Denies Moody Bond-Calls Him Danger to Other Persons, ATLANTA J. \& CONST., July 14, 1990, at C1.

274. Moody, 746 F. Supp. at 1091.

275. Id.

276. Id.

277. Id. at 1092.

278. Id.

279. See, e.g., United States v. Simone, 14 F.3d 833, 835 (3d Cir. 1994) (regarding in camera examinations of jurors for possible exposure to prejudicial publicity); United States v. Smith, 787 F.2d 111, 112 (3d Cir. 1986) (concerning access to transcripts to sidebar and bench conferences); Capital Newspapers Group of Hearst Corp. v. Brown, 429 N.Y.S.2d 749, 750-51 (N.Y. App. Div. 1980) (objection to closed hearing following a bench conference); Houston Chronicle Publ'g Co. v. Shaver, 630 S.W.2d 927, 929-30 (Tex. Crim. App. 1982) (media challenge to judge's consideration, in chambers, of voluntariness of a confession).

280. 289 U.S. 1, 6 (1933).

281. Id. at $13-14$. 
should have remained secret. ${ }^{282}$ In rejecting the juror's argument, the Court held that the privilege for jury deliberations did not apply to one who had acted fraudulently. ${ }^{283}$ In the absence of fraud by a juror, however, the Court said that deliberations would be privileged and kept secret to protect jurors" "[f]reedom of debate" and "independence of thought." 284

Nevertheless, the media have shown interest in gaining access to jury deliberations. In 2002, the Public Broadcasting Service's Frontline news program obtained permission from a trial judge to videotape a capital murder trial in Texas, including deliberations by the jury. ${ }^{285}$ Frontline's plan was to broadcast the video after the trial. ${ }^{286}$

A Texas appellate court intervened, however, ruling that the order permitting Frontline to videotape the jury deliberations violated a statute that said "[n]o person shall be permitted to be with a jury while it is deliberating." 287 Dissenting, one of the appellate judges said:

The question in this case is whether allowing a camera in the jury room to record the jury while it is deliberating violates the statute's proscription against a "person" being with the jury. The majority concludes that "each of the millions of viewers of the videotape is a person" and that "the playing of the videotape (live or not) permits these persons to 'be with the jury while it is deliberating'." But this is simply not the case. While each viewer is indeed a person, the viewers will not be with the jury while the jury is deliberating. Instead, the viewers will be viewing the jury long after the jury has deliberated.

\section{Anonymous Juries}

Even when presiding over a trial that is open, the judge may shield the jurors from public scrutiny by keeping their identities secret. Anonymous juries are requested in organized crime cases and in trials of terrorists. ${ }^{289}$ As has been reported, "[h]istorically, these are cases in

282. Id.

283. Id. at $14-15$.

284. Id. at 13

285. University of Texas at Austin School of Law, Court Hearing: UT-Austin to Host Oral Arguments in Cameras in Courtrooms Case, Jan. 10, 2003, http://www.utexas.edu/law/news/2003/ 011003_arguments.html.

286. Id.

287. State ex rel. Rosenthal v. Poe, 98 S.W.3d 194, 200 (Tex. Crim. App. 2003) (quoting TEX. CODE CRIM. PROC. ANN. art. 36.22 (Vernon 2006)).

288. Id. at 223 (Keasler, J., dissenting) (citation omitted).

289. Corinna Zarek, Trying Blind: Secret Juries Continue Hearing Major Cases, NEws MEDIA \& L., Fall 2007, at 23, available at http://www.rcfp.org/newsitems/index.php?i=6459. 
which a court is concerned about jury tampering and juror safety, fearing threats and retribution against jurors. ${ }^{, 290}$

The Kansas Supreme Court has prescribed when a trial judge may grant anonymity to jurors in criminal trials:

Empaneling an anonymous jury is viewed as a drastic measure which should be undertaken only under certain limited circumstances. The trial court must balance the need to ensure juror safety against the defendant's right to the presumption of innocence and the ability to conduct an effective voir dire. This balancing test is met where (1) there is strong reason to believe the jury needs protection and (2) the court takes reasonable precautions to minimize any prejudicial effects on the defendant and to ensure his or her fundamental rights are protected. $^{29}$

The court noted that states generally follow federal practice in requiring that a jury be anonymous only for "a compelling reason." 292 The court said a finding that a jury needs protection may be based on the following factors:

(1) the defendants' involvement in organized crime; (2) the defendants' participation in a group with the capacity to harm jurors; (3) the defendants' past attempts to interfere with the judicial process or witnesses; (4) the potential that, if convicted, the defendants will suffer a lengthy incarceration and substantial monetary penalties; and, (5) extensive publicity that could enhance the possibility that jurors' names would become public and expose them to intimidation and harassment. $^{293}$

\section{F. Access to Civil Proceedings}

\section{Presumed Open}

In Richmond Newspapers, the United States Supreme Court observed "that historically both civil and criminal trials have been presumptively open." 294 Since then, lower courts have held that civil trials should be no less accessible to the press and public than criminal proceedings. For example, in Publicker Industries, Inc. v. Cohen, the Third Circuit said that "the civil trial, like the criminal trial, 'plays a particularly significant

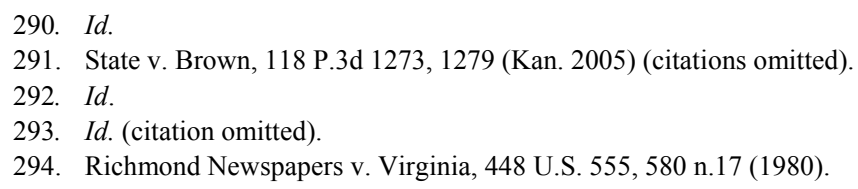


role in the functioning of the judicial process and the government as a whole." "295 Other points made in Publicker included these:

- "[P]ublic access to civil trials "enhances the quality and safeguards the integrity of the factfinding process." $" 296$

- Openness is associated with fairness and "heightens 'public respect for the judicial process.'

- Access to civil proceedings " "permits the public to participate in and serve as a check upon the judicial process-an essential component in our structure of self-government."

- "Public access to civil trials, no less than criminal trials, plays an important role in the participation and the free discussion of governmental affairs."

In Kansas, state courts have focused on access to criminal matters, although a federal court in the state has ruled in favor of open civil proceedings. A defendant in Mike v. Dymon, Inc. allegedly breached an employment contract by making an unauthorized disclosure about a business. $^{300}$ The defendant, without objection from the plaintiff, asked that the courtroom proceedings "be closed to unauthorized personnel during presentation or discussion of 'competitive confidential' or 'confidential' information." 301 In rejecting the request for closure, the judge recognized "that members of the public possess both a common law and First Amendment right of access to civil trials." 302 One cited precedent said:

[W]hat happens in the halls of government is presumptively open to public scrutiny. Judges deliberate in private but issue public decisions after public arguments based on public records. The political branches of government claim legitimacy by election, judges by reason. Any step that withdraws an element of the judicial process from public view makes the ensuing decision look more like fiat; this requires rigorous justification.

295. 733 F.2d 1059, 1070 (3d Cir. 1984) (quoting Globe Newspaper Co. v. Superior Court, 457 U.S. 596, 606 (1982)) (reversing a trial judge's denial of media access to civil proceedings in a stockholder dispute).

296. Id. (quoting Globe Newspaper, 457 U.S. at 606).

297. Id. (quoting Globe Newspaper, 457 U.S. at 606).

298. Id. (quoting Globe Newspaper, 457 U.S. at 606).

299. Id.

300. No. 95-2405-EEO, 1997 WL 38111, at *1 (D. Kan. Jan. 23, 1997).

301. Id.

302. Id. (citing Publicker, 733 F.2d at 1066-71).

303. In re Krynicki, 983 F.2d 74, 75 (7th Cir. 1992). 


\section{Selected Issues}

\section{a. Discovery}

A civil case may attract news media attention, particularly if it involves serious allegations or the litigants are prominent. In such a case, the media may seek access to pre-trial discovery proceedings. In New York, for example, Newsday once sought to attend depositions during a wrongful death action against a hospital. ${ }^{304}$ The case focused on a hospital employee who had been convicted of murder after being accused of improperly administering a drug to patients. ${ }^{305}$ In Scollo v. Good Samaritan Hospital, a New York appellate court recognized that the presumption of openness in Press-Enterprise II applied to civil proceedings, but ruled that Newsday was not entitled to attend the depositions. $^{306}$

The decision in Scollo was based on a 1994 United States Supreme Court decision. ${ }^{307}$ In that decision, Seattle Times Co. v. Rhinehart, a religious organization had sued the Seattle Times newspaper and others, alleging that they had published defamatory articles. ${ }^{308}$ After the lawsuit was filed, the trial judge ordered the newspaper not to make public certain information that the paper could gain about the plaintiff before trial through the discovery process. ${ }^{309}$ The newspaper was permitted to use the information from discovery only to defend itself in the course of litigation. $^{310}$

The Court upheld the restriction on the newspaper, observing that the judge's order did not prohibit the paper from publishing information that it gained by means other than discovery and that the judge had issued the order "to avoid the 'chilling effect' that dissemination would have on 'a party's willingness to bring his case to court." "'311 The Court went on to say:

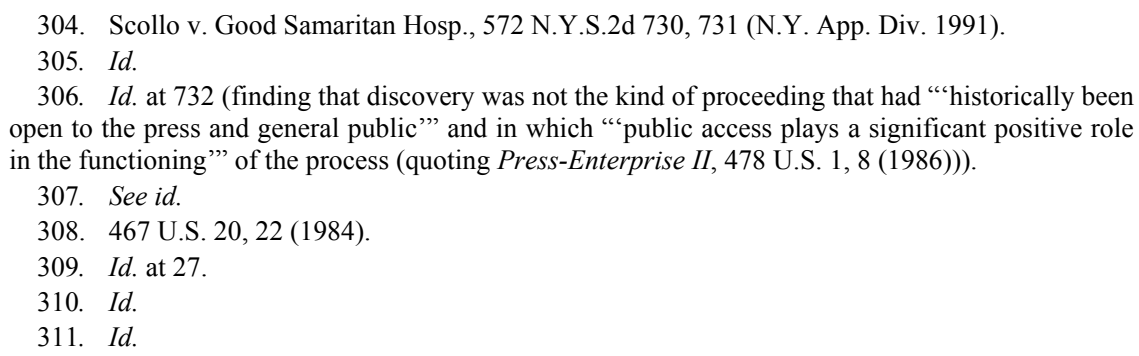


[P]retrial depositions and interrogatories are not public components of a civil trial. Such proceedings were not open to the public at common law, and, in general, they are conducted in private as a matter of modern practice. Much of the information that surfaces during pretrial discovery may be unrelated, or only tangentially related, to the underlying cause of action. Therefore, restraints placed on discovered, but not yet admitted, information are not a restriction on a traditionally public source of information.

\section{b. Bankruptcy}

A debtor in a 1987 bankruptcy proceeding tried to keep a Baltimore Sun reporter from attending a creditors' meeting, arguing that the meeting was like discovery and should be kept private. ${ }^{313}$ A U.S. District Court reviewed the case and said reasons for barring a reporter from a creditors' meeting could be "a concern (1) that the debtor would be less forthcoming regarding his financial situation in the presence of the press; and (2) that the presence of noninterested parties might interfere with the orderly administration of the proceedings."314 Nevertheless, the holding was that a creditors' meeting should be accessible to the media and the public. ${ }^{315}$ The court said:

[W]hile both discovery and a creditors' meeting are primarily concerned with obtaining information, the two proceedings have much different historical backgrounds. Discovery is a pretrial process conducted principally by the parties with varying degrees of court supervision; a creditors' meeting is a formal part of a Chapter 7 bankruptcy, mandated by [statute], supervised by a court clerk, and a proceeding at which substantive rights of creditors are often affected. ${ }^{316}$

The court also said that, in light of the history and law of bankruptcy, a creditors' meeting is presumptively open "unless, in a given case, there is a showing that a restriction of access "is essential to preserve higher values and is narrowly tailored to serve that interest." "317

312. Id. at 33 (citations omitted).

313. In re Astri Inv., Mgmt. \& Sec. Corp., 88 B.R. 730, 732 (D. Md. 1988).

314. Id. at 741 .

315. Id.

316. Id. at 736 .

317. Id. at 741 (quoting Press-Enterprise I, 464 U.S. 501, 510 (1984)). 


\section{OPENNESS OF COURT RECORDS}

\section{A. Protection for Truthful Publication}

A Kansas statute prohibits public disclosure of a search or arrest warrant without authorization from law enforcement. ${ }^{318}$ In 1979, the Kansas Supreme Court considered whether the statute could be enforced against a newspaper after it identified persons for whom authorities had issued arrest warrants. ${ }^{319}$ After the paper disclosed the names, the authorities were unable to locate one of the persons and found the other only several weeks later out of state. ${ }^{320}$ The newspaper was convicted of violating the non-disclosure statute. ${ }^{321}$ In State v. Stauffer Communications, however, the Kansas Supreme Court reversed the conviction. ${ }^{322}$ The newspaper, the Topeka Daily Capital, had learned about the warrants by monitoring the police radio, and a reporter verified the names by checking a criminal appearance docket in the office of the clerk of the district court. ${ }^{323}$ She had gained access to the appearance docket by following the general practice for reporters, which was to walk past a counter in the office and through a gate to a table at the back of the room. ${ }^{324}$ There, they could view the appearance docket, a public record kept by the clerk of the district court. ${ }^{325}$ The court held:

The First Amendment to the United States Constitution and Section 11 of the Bill of Rights of the Kansas Constitution forbid the imposition of criminal sanctions for truthful reporting of facts gleaned from public records. By placing information in the official public records the state has thereby released the information to the public and has placed it in the public domain. ${ }^{326}$

The holding in Stauffer was in accord with a line of precedents that protect truthful reporting of information gained in open court or gleaned from public records. As was stated in one case, "“[a] trial is a public event. What transpires in the court room is public property.... Those

\footnotetext{
318. KAn. Stat. ANN. § 21-3827 (2007).

319. State v. Stauffer Commc'ns, 592 P.2d 891, 892 (Kan. 1979).

320. Id. at 893 .

321. Id. at 892 .

322. Id. at 897 .

323. Id. at 893 .

324. Id.

325. Id.

326. Id. at 894-95.
} 
who see and hear what transpired can report it with impunity.",327 In another, the United States Supreme Court said:

As a general matter, "state action to punish the publication of truthful information seldom can satisfy constitutional standards." More specifically, this Court has repeatedly held that "if a newspaper lawfully obtains truthful information about a matter of public significance then state officials may not constitutionally punish publication of the information, absent a need... of the highest order."328

\section{B. Access and the Common Law}

A common law right of access to court records has been recognized in support of "the citizen's desire to keep a watchful eye on the workings of public agencies and in a newspaper publisher's intention to publish information concerning the operation of government." 329 Under the common law, however, a judge has discretion to deny access to court records if they could become "a vehicle for improper purposes." 330

The Kansas Supreme Court has concluded that such improper purposes include use of records "'to gratify private spite or promote public scandal' through the publication of the details of a divorce case or for the publication of libelous statements for press consumption, or as sources of business information that might harm a litigant's competitive standing." 331

\section{Statutory Right of Access}

The United States Supreme Court has observed that, in many jurisdictions, the common law right of access to court records "has been recognized or expanded by statute." ${ }^{332}$ To the extent that the Kansas Legislature has codified common law access, it has done so principally through the Kansas Open Records Act. ${ }^{333}$ The Legislature declared that

327. Cox Broad. Corp. v. Cohn, 420 U.S. 469, 492 (1975) (emphasis added) (quoting Craig v. Harney, 331 U.S. 367, 374 (1947))

328. Bartnicki v. Vopper, 532 U.S. 514, 527-28 (2001) (citing Smith v. Daily Mail Publ'g Co., 443 U.S. 97, 102 (1979)); see also Fla. Star v. B.J.F., 491 U.S. 524, 550 (1989); Landmark Commc'ns, Inc. v. Virginia, 435 U.S. 829, 842 (1978).

329. Nixon v. Warner Commc'ns, Inc., 435 U.S. 589, 598 (1978).

330. Id.

331. Stephens v. Van Arsdale, 608 P.2d 972, 982 (1980) (quoting Warner Commc'ns, 435 U.S. at 598).

332. Warner Commc'ns, 435 U.S. at 598 n.7.

333. See Kan. Stat. AnN. §§ 45-215 to 45-223 (2000 \& Supp. 2008). 
openness of public records is presumed, ${ }^{334}$ and made the law applicable to any "public agency," including any "entity receiving or expending and supported in whole or in part by the public funds appropriated by the state." 335

The Open Records Act, however, also provides that a public agency "shall not be required to disclose" certain records, such as those closed by supreme court rule. ${ }^{336}$ The Kansas Supreme Court has exercised its authority by issuing an order providing for "Administration of the Kansas Open Records Act.",337

The Kansas Judicial Branch has reported on its website that open court records include "case files and transcripts" and "[f]inal civil and criminal judgments." 338 The Judicial Branch also has made clear that some records are not accessible "pursuant to judicial order or caselaw" and that the Open Records Act "recognizes that some records contain information that is private in nature.",339

Judges' records are an example of records that are exempt from public inspection under the Open Records Act. The exemption excludes "any municipal judge, judge of the district court, judge of the court of appeals or justice of the supreme court" from the requirement that public agencies must make their records available. ${ }^{340}$ Long distance telephone records of judges are an example of the kind that are considered exempt. $^{341}$

Judges, however, must make an annual public disclosure of certain personal financial matters under a Kansas Supreme Court rule. ${ }^{342}$

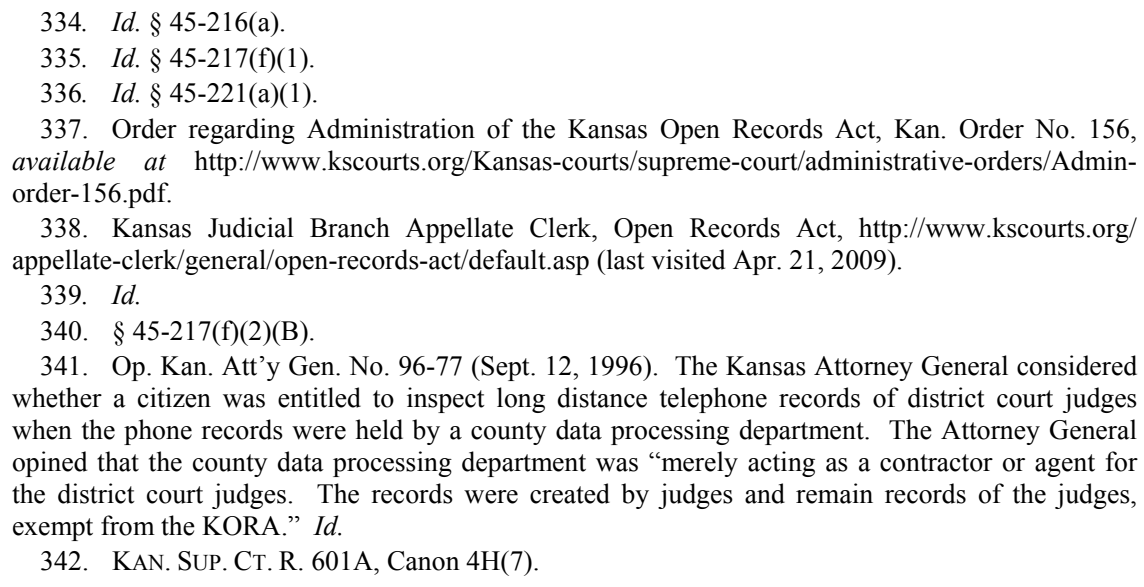

338. Kansas Judicial Branch Appellate Clerk, Open Records Act, http://www.kscourts.org/ appellate-clerk/general/open-records-act/default.asp (last visited Apr. 21, 2009).

339. Id.

340. § 45-217(f)(2)(B).

341. Op. Kan. Att'y Gen. No. $96-77$ (Sept. 12, 1996). The Kansas Attorney General considered whether a citizen was entitled to inspect long distance telephone records of district court judges when the phone records were held by a county data processing department. The Attorney General opined that the county data processing department was "merely acting as a contractor or agent for the district court judges. The records were created by judges and remain records of the judges, exempt from the KORA." Id.

342. Kan. Sup. CT. R. 601A, Canon 4H(7). 


\section{Access to Records and the First Amendment}

\section{Standard Adopted in Fossey}

In 1980, the Kansas Supreme Court declared that access to court records was governed by common law, not the First and Fourteenth Amendments. ${ }^{343}$ A year later in Fossey, ${ }^{344}$ however, the Kansas Supreme Court took a more favorable view of the First Amendment's application to court records. According to Fossey, "'The public interest in open proceedings and free access to courts in a criminal case is at least as strong as the first amendment policy against prior restraints." "345 The 1976 landmark First Amendment precedent, Nebraska Press, ${ }^{346}$ was the basis for the standard that the Kansas Supreme Court adopted on court access in Fossey. ${ }^{347}$ The standard states that a motion to seal a court record may be granted only when a judge finds that: 1) "the dissemination of information from the ... record would create a clear and present danger to the fairness of the trial," and 2) "the prejudicial effect of such information on trial fairness cannot be avoided by any reasonable alternative means." ${ }^{448}$

The standard also requires that a "complete record" be kept of any pre-trial proceeding that a judge conducts in a closed courtroom or in chambers because of a clear and present danger of unfairness. The record of the closed proceeding must be "made available to the public following the completion of trial or earlier if consistent with trial fairness." 349

\section{Federal Courts}

A First Amendment right of access to records has been claimed with some success in federal courts. ${ }^{350}$ They include the Tenth Circuit,

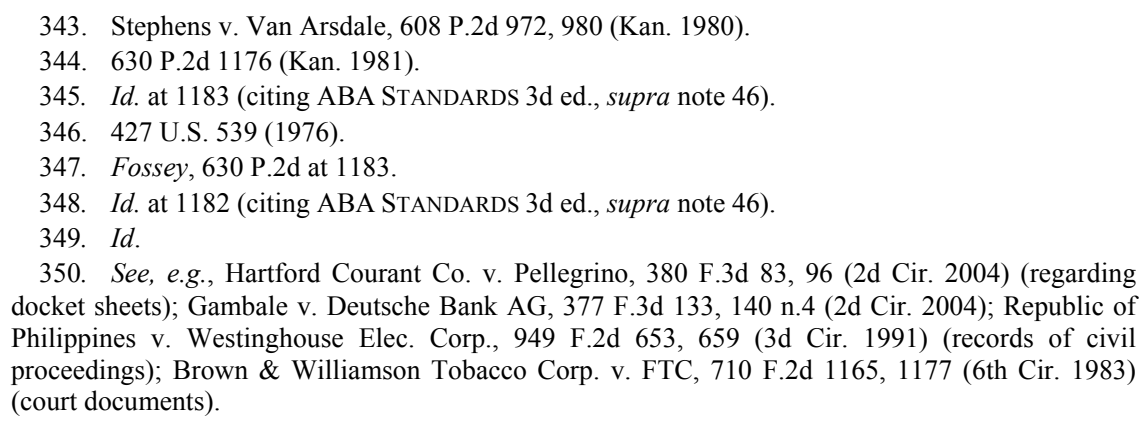


although it only recognized a First Amendment access right in a limited way. A district judge in Colorado had sealed records in connection with the criminal proceedings that followed the 1995 bombing of the Murrah Federal Building in Oklahoma City, Oklahoma. In United States v. McVeigh, the Tenth Circuit noted that, under the common law, court records "are presumptively available to the public, but may be sealed if the right to access is outweighed by the interests favoring nondisclosure." 351 The common law, it also was noted, provides that a judge's decision to seal records may be reviewed for abuse of discretion. ${ }^{352}$

Before sealing the records in the Oklahoma City bombing case, however, the Colorado district judge had applied a First Amendment standard rather than the common law. The Tenth Circuit observed that, in a number of other federal courts, "the logic of Press-Enterprise II extends to at least some categories of court documents and records, such that the First Amendment balancing test there articulated should be applied before such qualifying documents and records can be sealed." 353 The court declined to hold that the media generally have a First Amendment-based right of access to court records. ${ }^{354}$ Nevertheless, in its review of the media's request for records in the Oklahoma City bombing case, the court assumed that access in that specific case was "governed by the analysis articulated in Press-Enterprise II."355 The court explained:

In determining whether a particular type of document is included within the First Amendment right of access, courts engage in a twopronged inquiry in which they ask: (1) whether the document is one which has historically been open to inspection by the press and the public; and (2) "whether public access plays a significant positive role in the functioning of the particular process in question." This two-part inquiry is referred to as the test of "experience and logic."

If the qualified First Amendment right of access is found to apply to the documents under the "experience and logic" test, [a] court may then seal the documents only if "closure is essential to preserve higher values and is necessary to serve that interest.",356

\footnotetext{
351. 119 F.3d 806, 811 (10th Cir. 1997) (citing Nixon v. Warner Commc'ns, Inc., 435 U.S. 589, $602(1978))$.

352. Id.

353. Id.

354. Id. at 812,814 .

355. Id. at 812 .

356. Id. at 812-13.
} 
The court upheld the district judge's sealing of the records, concluding that when records are closed to the extent permissible under the First Amendment, the closure necessarily also satisfies the common law standard. ${ }^{357}$

\section{E. Legislation Regarding Sealed Records}

In 2008, the Kansas Legislature enacted a law that requires state courts to conduct a hearing before they seal records or close a proceeding. ${ }^{358}$ The law requires judges to specify their reasons for denying access to proceedings or records and base their decision on an "identified safety, property or privacy interest." ${ }^{359}$ In proposing the law, which originated as House Bill 2825, the sponsor acted in "response to concerns regarding the practice of the Kansas Supreme [Court] closing proceedings in certain high profile cases." 360

\section{F. Certain Types of Criminal Records}

\section{Warrants and Supporting Affidavits}

\section{a. Access Sought in Kansas}

Kansas media have objected to limitations that state laws impose on access to information about arrest and search warrants. One statute recognizes the authority of government officials to control the release of information about warrant applications and execution of warrants. ${ }^{361}$

\footnotetext{
357. Id. at 812 .

358. See Kan. Stat. AnN. § 60-2617 (Supp. 2008).

359. Id. § 60-2617(d).

360. Lance Kinzer, Legislative Update-April 15, 2008, http://www.lancekinzer.com/041508 update.html. The sponsor of H.B. 2825, Rep. Lance Kinzer (R-Olathe), identified the Kansas Supreme Court cases that concerned him as Comprehensive Health of Planned Parenthood of Kan. \& Mid-Mo., Inc. v. Kline, 197 P.3d 370 (Kan. 2008), and State ex rel. Six v. Anderson, No. 99050 (Kan. Jan. 30, 2009). The judicial proceedings that concerned Rep. Kinzer focused on allegations by former Johnson County District Attorney Phill Kline against former Attorney General Paul Morrison. Kline questioned Morrison's purpose in gathering certain medical records in 2007. Kline contended that Morrison's purpose was not to investigate a Wichita doctor, George Tiller, or Planned Parenthood of Overland Park for criminal wrongdoing related to abortions. Rather, Kline contended, Morrison's purpose was to return the records and prevent further investigation. Morrison and Planned Parenthood took legal action against Kline and Judge Richard Anderson, who had played a role in the dispute over the records. When the matter was appealed, court hearings were closed, and records were sealed. See Kevin Wright, Kline Accuses Morrison of Gathering Documents for False Purpose, Olathe DAILY NEwS, Feb. 19, 2008, available at http://www.theolathenews.com/101/story/53039.html.

361. See $§ 21-3827$ (2007).
} 
Other statutes limit access to law enforcement affidavits that state the probable cause for issuing warrants. Such affidavits generally "shall not be made available for examination without a written order of the court"; the only exception is for access by a defendant or the defendant's lawyer. ${ }^{362}$ Even after a warrant is executed and returned, media access to information about it may be denied if the warrant or affidavit relates to an on-going criminal investigation. The Kansas Open Records Act specifically provides that disclosure of a criminal investigation record is not required, although a judge may order that it be opened to serve the public interest and under certain other conditions. ${ }^{363}$

The Kansas Press Association has urged that the Legislature provide greater access to warrant information. For example, in 2006, Senate Bill 415 was introduced as part of an effort to make search warrant affidavits accessible. ${ }^{364}$ The bill, which died in committee, proposed that affidavits be open to the public "after the defendant waives preliminary trial or is bound over for trial" and in certain other circumstances. ${ }^{365}$ In 2007, Senate Bill 132 proposed greater access to information about arrest warrants after they have been executed. ${ }^{366}$ Under the proposal, which remained in a committee, affidavits filed with executed arrest warrants would

be public court records following the exclusion of information that would:

(a) Interfere with any prospective law enforcement action, criminal investigation or prosecution;

(b) reveal the identity of any confidential source or undercover agent;

(c) reveal confidential investigative techniques or procedures not known to the general public;

(d) endanger the life or physical safety of any person; or

362. See id. § 22-2302(2) (limiting affidavits on arrests); id. § 22-2502(c) (limiting affidavits pertaining to searches).

363. See id. § 45-221(a)(10) (Supp. 2008).

364. S.B. 415, 2006 Sess. (Kan. 2006), available at http://www.kslegislature.org/bills/2006 1415.pdf (proposing amendment of § 22-2502).

365. See id.

366. S.B. 132, 2007 Sess. (Kan. 2008), available at http://www.kslegislature.org/bills/2008 1132.pdf (proposing amendment to $\S 22-2302$ ). 
(e) reveal the name, address, phone number or any other information which specifically and individually identifies the victim of any
sexual offense ....

Some members of the Kansas media have taken the position that the state "is out of step with most other states in keeping probable cause affidavits, filed in support of arrest warrants, under seal even after a case has gone to trial." 368 The editor of the Wichita Eagle has been quoted as saying that criminal proceedings "should not be conducted behind a curtain. When they are, citizens are denied a critical opportunity to assess the effectiveness of the criminal justice system.

\section{b. Federal Restrictions}

Federal courts have not generally granted access to search warrant affidavits. In the late 1980s, for example, the Baltimore Sun unsuccessfully sought access to an affidavit that an FBI agent had prepared to support the issuance of search warrants during a federal investigation of the health insurance industry. ${ }^{370}$ The Fourth Circuit held that the affidavit was a judicial record because such a document is subject to judicial review and a judge is responsible for filing it with the clerk of court. ${ }^{371}$

The Fourth Circuit noted that a split of opinion existed "on the press's first amendment right of access to search warrant affidavits.",372 The court, however, decided that the news media do not have a First Amendment right of access to search warrant affidavits, because the affidavits historically have not been open to the public. ${ }^{373}$ In addition, warrant papers are not open, because "the subject of the search cannot be tipped off to the application for a warrant lest he destroy or remove the evidence." 374

Recognizing that, apart from the First Amendment, the media have a common law "qualified right of access," the Fourth Circuit said that a judge must consider "all of the relevant facts and circumstances" in

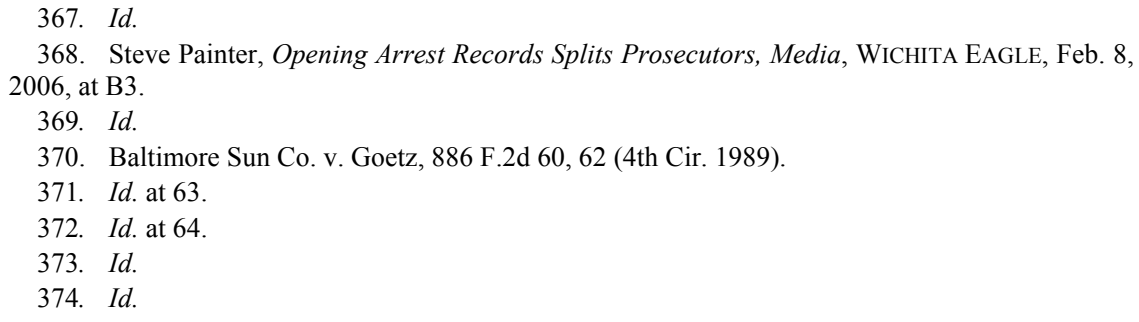


deciding whether to file warrant papers under seal or determining that secrecy is not justified. ${ }^{375}$

In 1992, a federal district court in Kansas adopted the Fourth Circuit's position that warrant papers are not accessible as a matter of First Amendment right. ${ }^{376}$ The district court also declined to grant access under the common law because of the "sensitive nature of the information contained" in the affidavits, the fact that a criminal investigation was ongoing, and a need to protect the identities and the "privacy interests and safety" of persons mentioned in the affidavits. ${ }^{377}$

\section{Evidentiary Exhibits}

As journalists report on pre-trial proceedings and trials in criminal cases, they often want to inspect evidence that will bear strongly on the question of a defendant's guilt or innocence. However, attorneys or judges may oppose making evidence available to journalists on grounds that public disclosure could unfairly prejudice jurors or invade the privacy of a trial participant. Disputes over access to evidence can be time-consuming and costly.

For example, after prosecutors filed charges in connection with highly publicized homicides in late 2000 in Wichita, a district judge sealed evidence related to the cases. ${ }^{378}$ After a media challenge to the sealing, ${ }^{379}$ another judge ruled in favor of media access to 911 call transcripts and autopsy and firearms testing results, saying they should be available under the Kansas Open Records Act. ${ }^{380}$ A defendant in the homicide cases appealed seeking to block access, but was unsuccessful. $^{381}$ Despite the county district attorney's continuing objections, the media ultimately gained access to the evidence. ${ }^{382}$

375. Id. at 65 .

376. In re Flower Aviation of Kan., Inc., 789 F. Supp. 366, 367-68 (D. Kan. 1992).

377. Id. at 368 .

378. Ron Sylvester, Evidence Sealed in 4 Killings-The District Attorney's Office Has Obtained an Order Sealing Public Information in the Case of Four People Shot to Death in a Wichita Soccer Field, Wichita EAGLe, Dec. 30, 2000, at A9.

379. Wichita Eagle Beacon Co. v. Owens, 27 P.3d 881 (Kan. 2001); see infra note 445 and accompanying text.

380. Ron Sylvester, Judge Permits Public Access to Carr Case Records-A Judge Rules that Many - But Not All —of the Documents Sealed in the Case Should be Open to the Public, WichiTA EAGLE, Aug. 2, 2001, at B1.

381. Tim Potter, Court Upholds Public Release of Carr Records-Officials in Wichita Are Expected to Release the Information Today, Wichita EAGLE, Sept. 28, 2001, at B1.

382. Ron Sylvester, 911 Call in Quadruple Homicide Is Released, WiChitA EAGLE, Nov. 10, 2001 , at B1. 
In two recent federal cases involving media access to trial exhibits, the judges in both instances ruled in favor of openness. In 2007, a U.S. district judge in New Orleans refused to seal some trial exhibits in a case that focused on whether the Allstate Insurance Company had wrongfully failed to pay for damage caused by Hurricane Katrina. ${ }^{383}$ The judge said that Allstate did not want to produce manuals and documents that field adjusters had used after Hurricane Katrina. ${ }^{384}$ The company felt that production of the materials could "put the company at a competitive disadvantage." 385 The judge reasoned, however, that the materials should be disclosed because "[p]ublic access serves to enhance the transparency and trustworthiness of the judicial process, to curb judicial abuses, and to allow the public to understand the judicial system better."386

In 2006, in the trial of Zacarias Moussaoui in Alexandria, Virginia, a U.S. district court posted photographs and videos related to the 9/11 terrorist attacks on the World Trade Center, as well as recordings of last phone calls made by victims. ${ }^{387}$ The number of exhibits posted totaled $1202{ }^{388}$ Because of their graphic nature, the court marked eighteen of the exhibits "discretion advised." 389 The court was reportedly the first ever to post all exhibits from a trial online. ${ }^{390}$ Moussaoui had been indicted in December 2001, and later pled guilty to charges that he had conspired to hijack and fly an airplane into the White House. ${ }^{391}$ He was sentenced to life in prison. ${ }^{392}$

\section{Criminal History}

The extent to which a criminal's history may be publicly disclosed has been controversial. The Kansas Attorney General has opined that a

383. See Weiss v. Allstate Ins. Co., No. 06-3774, 2007 WL 2377119, at*5 (E.D. La. Aug. 16, 2007) ("Because Allstate has provided no justification that outweighs the well-established presumption in favor of public access to judicial records, the Court declines to place these exhibits under seal.").

384. Id. at *1.

385. Id. (quoting Allstate's motion for protective order).

386. Id. at *4 (citing Bahwell v. Stanley-Bostich, Inc., No. Civ. A. 00-0541, 2002 WL 1298777, at *1 (E.D. La. June 10, 2002)); see also La. District Court Says Allstate Trial Exhibits Must Remain Open, INS. J., Aug. 22, 2007, available at http://www.insurancejournal.com/news/southcentral/ 2007/08/22/82936.htm.

387. 9/11 Trial Exhibits Posted on Website, USA TODAY, July 31, 2006, available at http://usatoday.com/news/nation/2006-07-31-moussaoui-exhibits_x.htm.

388. Id.

389. Id.

390. Id.

391. Id.

392. Id. 
standard law enforcement arrest report is not an open record. ${ }^{393}$ An arrest report is entered on a form that includes detailed information about arrestees, such as their hair style, tattoos, and scars. ${ }^{394}$ An arrest report is classified as a criminal history record that is closed by statute. ${ }^{395}$ The Attorney General also has considered whether a standard offense report is the kind of record that may be closed. ${ }^{396}$ On the first page of an offense report, law enforcement authorities enter the description of a crime. $^{397}$ On the next page, they enter information about the method by which the crime was committed, evidence collected, and suspects who have been identified. ${ }^{398}$ Because the first page of an offense report contains basic, factual information, it is presumed to be open, but the second page is viewed as an investigative record and is closed. 399

In addition to the first page of the standard offense report, jail rosters and police blotters are open records. ${ }^{400}$ In providing access to these records, the Legislature

was recognizing the common law right of access to information on arrests and intended for the public and press to have access to basic information on arrests at a point reasonably contemporaneous with the arrest. This access may come in the form of access to police blotters. If a law enforcement agency does not maintain information on arrests in a blotter, we believe the law enforcement agency has an obligation to make basic blotter-type information about arrests available reasonably contemporaneously with the arrest. ${ }^{41}$

Now, a movement to restrict access to criminal history information has emerged. An American Bar Association Commission on Effective Criminal Sanctions sponsored "a series of resolutions that advocate drastically curtailing the public's access to felony conviction and arrest records." 402 The ABA commission was concerned about persons who

\footnotetext{
393. See Op. Kan. Att'y Gen. No. 98-38, at 1 (July 14, 1998) (“Standard Arrest Reports are mandatorily closed.").

394. Id. at 6 .

395. Id. at 7 (citing KAN. STAT. ANN. § 22-4707 (2007) (prohibiting dissemination of criminal history information)).

396. Id. at 4 .

397. Id.

398. Id.

399. Id. (citing § 45-217(c) (Supp. 2008) (defining criminal investigation records) and § 45221(a)(10) (stating that criminal investigation records may be closed)). These statutory sections are provisions of the Kansas Open Records Act (KORA) §§ 45-215 to 45-223 (2000 \& Supp. 2008).

400. See id. at 8 ("[J]ail rosters and police blotter entries are expressly excepted from KORA's definition of criminal investigation records.").

401. Id. at 9 .

402. Loren Cochran, Blacking Out the Blotter, News Media \& L., Summer 2007, at 18, 19.
} 
have been convicted of a crime and who have trouble qualifying for housing and employment because their criminal history information is so readily available, particularly through the Internet. ${ }^{403}$ The solution proposed by the ABA commission was to provide "a way for members of the public to petition courts to unseal a file. But instead of a criminal defendant having to prove a file should be sealed, the responsibility would shift to the public to prove that it should be unsealed." 404

Charles D. "Chuck" Tobin, a media lawyer in Washington, D.C., objected to the proposal, saying "'[i]t completely reverses the presumption that has been built in four decades of media law ... [as the] Supreme Court has developed a very strong presumption of public access to all proceedings and records in the courts.",405

\section{Expungement}

Like other states, Kansas allows persons convicted of certain crimes to expunge their convictions from court records. The state's expungement statute establishes a process and standards by which a judge may order expungement and lists a limited number of persons who may have access to an expunged conviction. ${ }^{406}$ Those with access range from the "person whose record was expunged" to law enforcement officers who are checking the background of an applicant for a position in law enforcement. ${ }^{407}$

Although the statute does not allow members of the public and the media to view expunged convictions, a newspaper reporter's request for access was considered in a 1980 case, Stephens v. Van Arsdale. ${ }^{408}$ The Kansas Supreme Court upheld a county court clerk's decision to deny the reporter's request, concluding that expungement as authorized by the state legislature is "reasonable and serves a valid and legitimate public purpose." 409 The court, however, also recognized "the inherent power which courts have over their official records" and said that "a district court might in its discretion permit the release of certain documents contained in an expunged file in order to achieve the ends of justice."

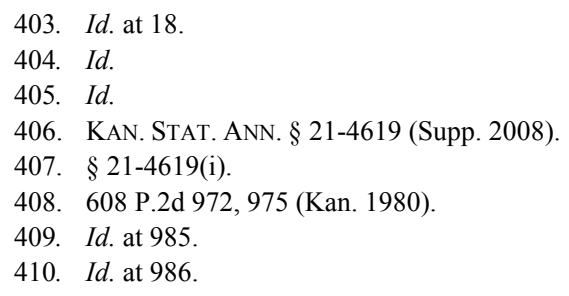


For example, an expunged conviction might be opened if a newspaper needs it to prove truth as a defense against a defamation claim. ${ }^{411}$ In 1992, the court considered whether a trial judge properly had allowed a litigant to use expunged convictions to impeach a witness in a medical malpractice case. ${ }^{412}$ Although the trial judge's decision was reversed, "the conclusion in Van Arsdale that the courts have inherent power over their official records" was affirmed. ${ }^{413}$

\section{G. Juror Information}

A 1980 report by the Judicial Conference of the United States took into account the possibility that, if jurors serve anonymously in a trial, court records that contain identifying information about them may be withheld. A conference committee comment in the report said that, by a "special order," a judge might direct "that the names and addresses of jurors or prospective jurors not be publicly released except as required by statute." "414

In the late $1980 \mathrm{~s}$, a noteworthy precedent was set in response to a media request for access to information about jurors in a federal criminal case. The trial judge refused to give the Baltimore Sun access to a venire list that contained information from questionnaires that prospective jurors had completed. ${ }^{415}$ The list included "their names, addresses, occupations, marital status, spouse's name and spouse's occupation."416 The Fourth Circuit, however, held that some of the information was a matter of public record, saying that after jurors are seated, their names "are just as much a part of the public record as any other part of the case, and we think so also are their addresses in order to identify them." ${ }^{417}$ At the same time, the names and addresses of prospective jurors who are not selected also become a matter of public record. The court explained:

411. See id. at 985-86 (arguing a court may consider releasing expunged files in causes of action for libel or slander).

412. Pope ex rel. Juby v. Ransdell, 833 P.2d 965, 975 (Kan. 1992).

413. Id. at 978 .

414. Marc O. Litt, "Citizen-Soldiers" or Anonymous Justice: Reconciling the Sixth Amendment Right of the Accused, the First Amendment Right of the Media and the Privacy Right of Jurors, 25 Colum. J.L. \& Soc. Probs. 371, 376 n.28 (1992) (quoting REvised REPORT OF THE JUdicial CONFERENCE COMMITTEE ON THE OPERATION OF THE JURY System ON THE "FreE PRESS-Fair TRIAL" ISSUE, 87 F.R.D. 518, 530 (1980)).

415. In re Baltimore Sun Co., 841 F.2d 74, 75 (4th Cir. 1988).

416. Id.

417. Id. 
[T] he risk of loss of confidence of the public in the judicial process is too great to permit a criminal defendant to be tried by a jury whose members may maintain anonymity. If the district court thinks that the attendant dangers of a highly publicized trial are too great, it may always sequester the jury; and change of venue is always possible as a method of obviating pressure or prejudice. ${ }^{418}$

Information beyond juror names and addresses should not be disclosed "unless some question concerning the same should properly arise within the case being tried."

In 2002, the question of media access to juror information received thorough consideration in an Ohio case. ${ }^{420}$ The Supreme Court of Ohio said that voir dire was presumptively open and that juror questionnaires "expedite the examination of prospective jurors." 221 The court concluded:

Accordingly, the First Amendment qualified right to open proceedings in criminal trials extends to prospective juror questionnaires. Consistent with our reasoning, we note that virtually every court having occasion to address this issue has concluded that such questionnaires are part of voir dire and thus subject to a presumption of openness.

\section{H. Civil Court Records}

Although access to court records usually is considered in the context of criminal proceedings, the media also may assert that a presumption of openness applies to records in civil cases. For example, the Seventh Circuit has ruled in favor of media access to records in shareholder actions against corporations. In In re Continental Illinois Securities Litigation, the Seventh Circuit said that "the policy reasons for granting public access to criminal proceedings apply to civil cases as well... . These policies relate to the public's right to monitor the functioning of our courts, thereby insuring quality, honesty and respect for our legal system." 423

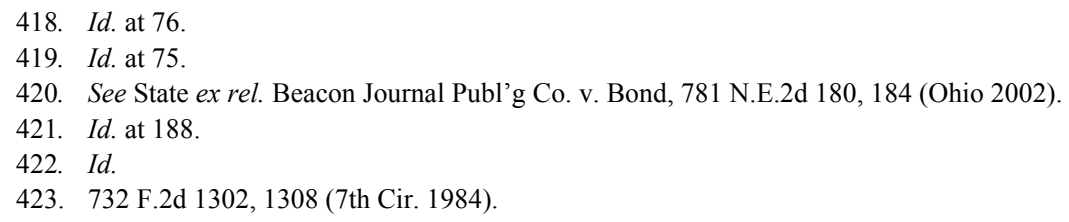




\section{Depositions}

A court may act to protect a record of a deposition against public disclosure. In a 1999 federal case, the defendants wanted to videotape a deposition, and the court found that their motive was "at least in part to generate notoriety for themselves and their business ventures by making non-litigation use of the videotape." 424 The court allowed the videotaping but ordered that it "be used solely for purposes of the litigation." 425

\section{Confidential Settlement Agreements}

Concern about confidential settlement agreements has mounted in recent years following highly publicized litigation against large companies and organizations. In cases against tire manufacturers, for example, plaintiffs blamed defective tires for traffic accidents that resulted in death or injury. When the manufacturers settled, however, they maintained secrecy about the alleged tire defects with court approval. $^{426}$ Also noteworthy was litigation against churches in recent years, in which plaintiffs claimed they had been molested by priests. Under court-approved confidentiality agreements, the churches suppressed information about patterns in sexual abuse over many years. $^{427}$

Sandra Baron, executive director of the Media Law Resource Center in New York, a critic of confidential settlements, has said that they prevent the public from learning about dangers that are documented in litigation. ${ }^{428}$ She said that confidential settlement agreements result "“in a great deal of information about matters that are in the public interest being buried, and they usually aren't buried forever.... They're buried just long enough for a lot of other people to get hurt." $" 429$

The Kansas Legislature has indicated that it disfavors secret settlements. In an interpretation of the Kansas Open Records Act, the Kansas Attorney General has said that a settlement agreement entered

424. Paisley Park Enters., Inc. v. Uptown Prods., 54 F. Supp. 2d 347, 348 (S.D.N.Y. 1999); see also Drake v. Benedek Broad. Corp., 28 Med. L. Rptr. 1542 (D. Kan. 2000) (allowing video recording of the deposition subject to protective measures).

425. Paisley Park Enters., Inc., 54 F. Supp. $2 d$ at 349.

426. Robert Schwaneberg, The Dilemma of the Secret Settlements, STAR-LEDGER (Newark, N.J.), Oct. 19, 2003, at 1.

427. Id.

428. Id.

429. Id. 
into by a city is a public record, and it cannot be confidential. ${ }^{430}$ If a contractual provision attempts to close the conditions of the settlement agreement, it "is void as against public policy." 431 In addition, Kansas law now allows a court to seal or redact records only after finding that a safety, property, or privacy interest "outweighs the strong public interest" in having access to information. ${ }^{432}$

According to a 2004 study of federal courts, the District of Kansas has rules "covering how long a document may remain sealed (after which it is returned to the parties, destroyed, or unsealed)." include "[n]o restriction on the court's authority to seal a document.",434

In general, the study found, a "common law presumption of access applies to documents filed with [federal] court[s], although it does not apply to documents exchanged in discovery... or to settlement agreements not filed." 435

\section{Selected Issues In AcCess to Court PRoceEdings AND RECORDS}

\section{A. Media Intervention}

\section{Procedure for Objection by a Reporter}

News reporters have learned to be alert if they are present when a judge considers a closure order. ${ }^{436}$ They have been advised to be prepared to stand, respectfully request to be heard, and voice an objection. ${ }^{437}$ Following is a sample statement of objection:

I am (name), a reporter for (newspaper or broadcaster.) On behalf of both myself and my (paper or station), I would like to note an objection to the closure of (or motion to close) this proceeding to the

\footnotetext{
430. Op. Kan. Att'y Gen. No. 93-55, at 2 (Apr. 20, 1993).

431. Id. at 1 .

432. KAN. Stat. ANN. § 60-2617(d) (Supp. 2008); see supra notes 358-60 and accompanying text (regarding enactment of H.B. 2825).

433. Robert timothy Reagan et al., Fed. Judicial Ctr., Sealed Settlement AGREEMENTS IN FEDERAL District COURT 2-3, 3 n.3 (2004), available at http://www.fjc.gov/ public/pdf.nsf/lookup/SealSet3.pdf/\$file/SealSet3.pdf.

434. Id. app. B, at B-11.

435. Id. at 1.

436. See Sam Klein \& Robert C. Clothier, Pa. Press Ass'n, Media Survival Kit 11-14 (6th ed. 2001), available at http://www.pa-newspaper.org/contentmanager/uploads/PDFs/mansi/ kit.pdf.

437. Id. at $11-12$
} 
public and press, and I request an opportunity to be heard through counsel prior to any closure of the proceedings.

If asked for the basis of your objection, state:

I understand that under the First Amendment to the United States Constitution (and, if in state court, the Constitution of [Kansas]) the press and public are afforded the right to attend court proceedings. At the very least, the law requires that a hearing be held, with the press given an opportunity to participate, prior to closure. These arguments can best be made by counsel and I request that our counsel be afforded an opportunity to be heard.

By reading such a statement, the reporter may gain time and opportunity for a lawyer to intervene and present arguments against closure.

\section{Standing to Intervene}

In 1981, when the Kansas Supreme Court ruled in favor of open court proceedings in Fossey, the media's standing to intervene and object to a trial judge's order was not in question. ${ }^{439}$ In that case, the media had filed a motion to intervene, asking the judge to vacate his order to close a proceeding and also requesting a copy of the transcript of the proceeding. ${ }^{440}$ After a hearing on the motion, the judge declined to vacate his closure order but granted the media's request for a transcript of the closed proceeding. ${ }^{441}$ The media then petitioned the Kansas Supreme Court for mandamus, ${ }^{442}$ seeking a declaration that the judge's closure order violated the First Amendment. ${ }^{43}$ Although the Kansas Supreme Court denied the petition for mandamus, it established the standard for openness that would apply in future cases. ${ }^{444}$ Reaffirming the media's standing to intervene, the court has said:

\footnotetext{
438. Language adapted from Pennsylvania Press Association Media Survival Kit. See id.

439. Kan. City Star Co. v. Fossey, 630 P.2d 1176, 1179, 1181-83 (Kan. 1981).

440. Id. at 1179.

441. Id.

442. Id. (stating that mandamus is an appropriate means to "expedite the official business of state officials in the discharge of their duties, where the issues are of significant statewide concern of a recurring and ongoing nature, and the essential purpose of the proceeding is to obtain an expeditious, authoritative interpretation of the law").

443. Id. at 1181.

444. See id. at 1181, 1184 ("[T] he reason for requiring all court proceedings to be open ... is to enhance the public trust and confidence in the judicial process and to insulate the process against attempts to use the courts as tools for prosecution.”).
} 
We believe an integral part of the rule announced in Fossey... is the need for a trial court, when considering the sealing of a record or the closure of a proceeding, to consider also the societal interest the public has in open criminal proceedings and records. The result here effectuates the Fossey rule. The news media, as a member of the public, should be permitted to intervene in a criminal case for the limited purpose of challenging a pretrial request, or order, to seal a record or close a proceeding in that case, even without an express statutory provision allowing such intervention.

\section{Standing as Analyzed in a Federal Case}

In 1998, in Koch v. Koch Industries, Inc., U.S. District Judge Crow analyzed the conditions under which the media may intervene in federal court. ${ }^{446}$ The media sought to object to the gag order that he had issued against trial participants, and Judge Crow acknowledged that the media had a right to intervene under certain conditions. ${ }^{447} \mathrm{He}$ said that, in challenging a gag order, the media "must allege an injury in fact- that the court's order impeded their ability to gather news and 'that impediment is within the zone of interest sought to be protected by the first amendment." 448 In addition, he indicated that the media's standing to challenge a gag order banning advertising would depend on the ban's impact on their financial interest. ${ }^{449}$

Judge Crow emphasized First Amendment protection for press freedom, saying:

[A]ny inhibitions against news coverage of a trial carry a heavy presumption of an unconstitutional prior restraint. If a court order burdens constitutional rights and the action proscribed by the order presents no clear and imminent danger to the administration of justice, the order is constitutionally impermissible. A court may impose a prior restraint on the gathering of news about one of its trials only if the restraint is necessitated by a compelling governmental interest.

445. Wichita Eagle Beacon Co. v. Owens, 27 P.3d 881, 883 (Kan. 2001).

446. 6 F. Supp. 2d 1185, 1188 (D. Kan. 1998), aff'd, 203 F.3d 1202 (10th Cir. 2000).

447. Id. at 1188; see supra notes 192-99 and accompanying text. Judge Crow noted that the media may intervene "as of right if: (1) the application is 'timely'; (2) 'the applicant claims an interest relating to the property or transaction which is the subject matter of the action'; (3) the applicant's interest may 'as a practical matter' be 'impair[ed] or impede[d]'; and (4) 'the applicant's interest is [not] adequately represented by existing parties." Koch, 6 F. Supp. 2d at 1188 (citing FED. R. CIV. P. 24(a)(2)).

448. Koch, 6 F. Supp. 2d at 1190 (quoting Journal Publ'g Co. v. Mechem, 801 F.2d 1233, 1235 (10th Cir. 1986)).

449. See id. at $1191 \mathrm{n} .9$ ("This ruling also obviates the need for the court to decide whether or not the movants' own financial interest is sufficient to confer standing to challenge the ban on advertising."). 
Moreover, the court must narrowly tailor any prior restraint and must consider any reasonable alternatives to that restraint which have a lesser impact on first amendment rights. These requirements apply for criminal trials as well as civil trials. ${ }^{430}$

The media argued that Judge Crow's gag order impaired their First Amendment interest in gathering and reporting news and engaging in commercial speech and also prevented them from gaining revenue from advertising sales. Judge Crow, however, ruled that the media did not have standing to intervene, although he made his decision only after balancing 'the parties' and public's interest in a fair trial against the competing interest in freedom of speech." 451 He found that the media lacked standing, in part, because the parties to the litigation had requested the gag order and said they did not want to talk to reporters. The media has no standing to intervene, he concluded, if the affected parties are not willing to speak publicly and be sources of news. ${ }^{452} \mathrm{He}$ also decided to dissolve his ban on advertising. ${ }^{453}$

In other federal courts, the media have successfully claimed standing to object to restrictive judicial orders. For example, the Second Circuit recognized that the media had standing to challenge a gag order issued against the prosecutors, defendants, and defense counsel in a trial on racketeering and other charges. ${ }^{454}$ The court found that the gag order adversely affected the media, because it interfered with their First Amendment-protected right to receive information. ${ }^{455}$ Defenders of the gag order argued that there were no willing speakers to serve as sources to the media. ${ }^{456}$ The court, however, said, "It is hard, in fact, to imagine that there are no willing speakers. Without them there would be no need for a restraining order; it would be superfluous. ${ }^{, 457}$ In another case, the Third Circuit decided that newspapers had standing to challenge a judicial order that had imposed confidentiality on a settlement agreement between a town and its former police chief. ${ }^{458}$ The court applied a straightforward principle, saying an intervener has standing when the

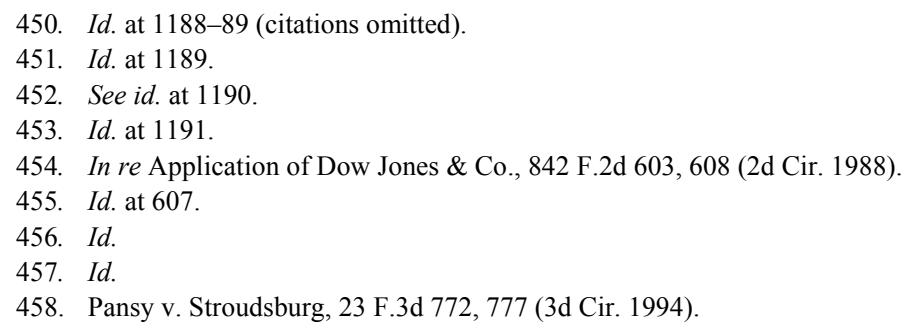


judicial order "being challenged presents an obstacle to the [media's] attempt to obtain access." $" 459$

\section{B. Secret Dockets}

The Reporters Committee for Freedom of the Press reported that "federal courts and many state courts allow for 'super-secret' cases, which never appear on the public docket or are hidden using pseudonyms, such as 'Sealed v. Sealed' or 'John Doe v. Jane Doe."”460

Kansas is not among states in which controversy has erupted over secret docketing, and case law on the subject nationally is minimal. ${ }^{461}$ In 2007, a federal district judge in Georgia, however, carefully examined the law governing sealing and secrecy. At the time, he was presiding over a criminal case that centered on prescription drug fraud. He said precedents made clear that there is a presumption

against secret documents, secret dockets, secret proceedings, and all the real and imagined sins that can be buried within. That's why "[j]udicial records presumptively are subject to public inspection."

The obvious rationale: this is a court of record precisely to enable public and appellate scrutiny and thus uphold confidence in the justice system itself.

\section{Using Court Records to "Out" Informants and Undercover Agents}

Although access to court records is widely recognized as being in the public interest, judges have been disturbed by some uses to which the records are put. Certain kinds of data from court records, if disseminated globally through the Internet, can invade privacy or create security risks. In 2008, for example, the Judicial Conference of the United States

459. Id.

460. Reporters Committee for Freedom of the Press, Secret Justice: Secret Dockets, Summer 2003, http://www.rcfp.org/secretjustice/secretdockets/index.html ("Courts that maintain these secret dockets will neither confirm nor deny the existence of such cases. As a result, these cases proceed through the court system undetected.").

461. As the Reporters Committee has noted, “There isn't much case law on the issue of secret docketing," although the practice has been held to be unconstitutional by the Second Circuit (covering Connecticut, New York, and Vermont) and the Eleventh Circuit (Alabama, Florida, and Georgia). Kirsten B. Mitchell, Reporting Tips, 30 News MEDIA \& L. 12 (Spring 2006), available at http://www.rcfp.org/news/mag/30-2/cov-reportin.html. Regarding the unconstitutionality of secret docketing, see United States v. Valenti, 987 F.2d 708, 715 (11th Cir. 1993), and Hartford Courant Co. v. Pellegrino, 380 F.3d 83, 96 (2d Cir. 2004).

462. United States v. Bradley, No. 405CR059, 2007 WL 2874888, at*1-2 (S.D. Ga. Sept. 26, 2007) (citations omitted). 
studied the dissemination of information through websites "whose purpose is to identify undercover officers, informants, and defendants who provide information to law enforcement." 463 The information had been gleaned from electronically available federal criminal case files, including plea agreements, that identified informants and undercover agents. ${ }^{464}$ One of the websites that features such information is called Who's a Rat; it bills itself as the "largest online database of informants and agents!" 465 At one point, the site claimed that it had identified 4300 informers and 400 undercover agents. ${ }^{466}$ Federal prosecutors were "furious," fearing that exposing the informers and agents would lead to "witness intimidation, retaliation and harassment."467 Judges and law enforcement authorities considered the possibility of sealing plea agreements or removing them from the federal courts' electronic records retrieval system. ${ }^{468}$ Judicial Conference committees that studied the problem received public comment that ran four-to-one in favor of retaining electronic access to plea agreements. ${ }^{469}$ As a result, the committees did not recommend eliminating access, suggesting instead that each federal court develop local rules to minimize the exposure of sensitive information, including plea agreements. ${ }^{470}$

\section{Courtroom Control}

\section{Use of Cameras as a Privilege}

When the media are present in courtrooms, their use of cameras and recording equipment can be a concern to trial judges who aim to minimize the effects of publicity on a defendant's right to a fair trial. Even so, the Kansas Supreme Court has granted the news media a "privilege" to photograph and record court proceedings.

The privilege, however, "does not limit or restrict the power, authority or responsibility of the judge to control" proceedings or to

\footnotetext{
463. Memorandum from James C. Duff, Director of the Administrative Office of the U.S Courts, to Chief Judges, U.S. Courts of Appeals; Judges, U.S. District Courts; and U.S. Magistrate Judges (Mar. 20, 2008) [hereinafter Duff Memorandum], available at http://www.federal defender.net/Documents/Scrolling_Banner/Plea_Agreements_memo_3-20-08.pdf.

464. Id. at 1 .

465. Who's a Rat, http://www.whosarat.com (last visited Apr. 21, 2009).

466. Adam Liptak, Web Sites Expose Informants, and Justice Dept. Raises Flag, N.Y. TimES, May 22, 2007, at A1.

467. Id.

468. See Duff Memorandum, supra note 463, at 1.

469. Id. at 2 .

470. Id. at $2-3$.
} 
"exclude the media or the public at a proceeding or during the testimony of a witness." which does not produce distracting light or sound may be used to cover a court proceeding." ${ }^{472}$

In Fossey, in 1981, the Kansas Supreme Court noted the responsibility of trial judges to manage their courtrooms, saying:

To safeguard the due process rights of the accused, a trial judge has an affirmative constitutional duty to minimize the effects of prejudicial pretrial publicity. And because of the Constitution's pervasive concern for these due process rights, a trial judge may surely take protective measures even when they are not strictly and inescapably necessary.

Douglas County District Judge Robert Fairchild is among Kansas judges who are open to the presence of cameras in the courtroom. In 2005, he allowed CBS's 48 Hours to videotape a high-profile murder trial. ${ }^{474}$ " "I have granted more access to the media (in this case) than I ever have," he told the jurors. ${ }^{475}$ His rules for coverage of the trial by 48 Hours, however, prohibited videotaping of the jury. ${ }^{476}$ He viewed the trial, with television coverage, as a "learning experience for the community." 777 After the trial, 48 Hours broadcast a program nationally about the case titled "A Mind for Murder.",

All fifty states allow media to record court proceedings to some extent, according to the Reporters Committee for Freedom of the Press. $^{479}$ In the federal judicial system, however, only two courts of appeal - the Second and Ninth Circuits - allow cameras, according to the Reporter's Committee, and no policy allows cameras in federal trial courts. ${ }^{480}$

471. KAN. SUP. CT. R. 1001.

472. Id.

473. Kan. City Star Co. v. Fossey, 630 P.2d 1176, 1181 (Kan. 1981) (quoting Gannett Co. v. DePasquale, 443 U.S. 368, 378-79 (1979)).

474. Steve Fry, Trial Attracts Media, TOPEKA CAP.-J., Feb. 2, 2005, at C1.

475. Steve Fry, '48 Hours' to Document Trial, TOPEKA CAP.-J., Feb. 17, 2005, at A1.

476. Id.

477. Id. This is a quoted paraphrase of Judge Fairchild's remark.

478. See Rebecca Leung, A Mind for Murder: Does A Beloved Professor Have A Mind For Murder?, CBS NEwS, Mar. 29, 2008, http://www.cbsnews.com/stories/2005/05/12/48hours/ main694835.shtml.

479. Corinna Zarek, House Committee Considers Camera Access to Federal Courts, News MEDIA UPDATE, Sept. 28, 2007, http://www.rcfp.org/news/2007/0928-bct-housec.html.

480. Id. 
At one point, bi-partisan support emerged in the U.S. House of Representatives for the Sunshine in the Courtroom Act of 2007. ${ }^{481}$ The purpose of the bill was to allow district court judges to exercise discretion over the media's use of cameras and recording equipment in courtrooms. ${ }^{482}$ In the U.S. Senate, however, a "move to allow TV coverage of all federal appellate and trial court proceedings was withdrawn after stiff opposition developed from members of both parties." $" 483$

\section{Sketch Artists}

An argument in support of sketch artists is that they should be permitted in the courtroom as long as they are not disruptive and their sketches would not adversely affect trial participants' ability to perform their roles in the judicial process. ${ }^{484}$ At times, however, cameras appear to be more welcome in courtrooms than sketch artists. Use of a sketch artist was restrained in a 2005 federal trial, in which the defendants were accused of engaging in sexual misconduct against mentally ill persons. In the case, United States v. Kaufman, the court found that federal law "proscribe[d] all forms of identification of the victims in [the] case, including... sketching for purposes of television." 485 The court also prohibited sketching of jurors. ${ }^{486}$

Another restraint was imposed against a sketch artist in a 2005 murder case in Douglas County. Judge Paula B. Martin ordered the Lawrence Journal-World not to publish an artist's sketches of adult witnesses in a murder trial. ${ }^{487}$ The judge concluded that "courtroom rules limiting photography of certain witnesses also apply to drawings by sketch artists." ${ }^{488}$ The judge later reversed her order, allowing publication of the sketches of the adults, but she separately ordered the

\footnotetext{
481. H.R. 2128, 110th Cong. (2007).

482. See id.

483. Terry Frieden, Panel OKs Bill to Televise Open Supreme Court Sessions, CNN.com, Dec. 6, 2007, http://www.cnn.com/2007/POLITICS/12/06/supreme.court.tv/index.html.

484. See Carrie Debra Stopek, Gag Orders: Enhancing Fair Trials or Impeding a Free Press?, 26 ARIZ. L. REV. 933, 943 (1984) ("A prior restraint on the media is justified only if the conduct of the press sketch artist is so distracting or disruptive that it disrupts the trial, and the judge believes the jury will decide the case based on fear instead of the evidence adduced at trial.").

485. No. 04-40141-01, 2005 WL 2648070, at *5 (D. Kan. Oct. 17, 2005) (applying The Crime Victims' Rights Act, 18 U.S.C. $\$ 3771$ (2000)).

486. Id.

487. See Eric Weslander, Judge Bars Sketches from Publication, LAWRENCE J.-WorLD, June 17, 2005 , at $6 \mathrm{~A}$.

488. Id
} 
newspaper not to publish sketches of two young teenagers who testified in the case. ${ }^{489}$

After filing a motion for reconsideration, which the judge denied, the World Company, publisher of the Journal-World, petitioned for mandamus in the Kansas Supreme Court. The World Company argued that the judge's order was erroneous because the rules regarding cameras in the courtroom are silent about sketch artists. ${ }^{490}$

Asserting that the judge's order was a prior restraint, the World Company said that it had been imposed without a hearing as constitutionally required. ${ }^{491}$ The World Company also argued that there was no need for the order, because an artist's sketch provides information to the public but yet is not sufficiently accurate to make witnesses identifiable and therefore does not jeopardize their privacy interests. ${ }^{492}$ The World Company moved for an expedited hearing, but was unsuccessful. The Kansas Supreme Court denied the World Company's petition about two months after the trial had ended. ${ }^{493}$

\section{Bloggers}

For judges, courtroom management now includes responding to requests for access from not only traditional journalists, but also bloggers.

In 2007, a federal court took an unprecedented step by allowing bloggers to be present during a high-profile trial alongside mainstream media representatives. ${ }^{494}$ During the trial of Vice President Cheney's former chief of staff on charges of perjury and obstruction of justice, the Washington Post reported:

[J]ournalists [were] expected to throng the federal courtroom in Washington, far too many for the 100 seats set aside for the media.

489. Eric Weslander, Judge Reverses Ruling Prohibiting Sketches, LAWRENCE J.-WORLD, June 21,2005 , at $4 \mathrm{~A}$.

490. Memorandum in Support of Petition for Writ of Mandamus at 2, World Co. v. Martin, No. 05-94706-S (Kan. June 17, 2005).

491. Id. at 5.

492. Id. at 2 .

493. Denial of Petition for Writ of Mandamus, World Co. v. Martin, No. 05-94706-S (Kan. Sept. 20, 2005); see also Associated Press, Lawrence Man Gets Life Term in Wife's Murder, July 21, 2005, http://www.wibw.com/home/headlines/1722132.html.

494. Alan Sipress, Too Casual To Sit on Press Row?-Bloggers' Credentials Boosted With Seats at the Libby Trial, WASH. POST, Jan. 11, 2007, at D1. 
But for the first time in a federal court, two of these seats will be reserved for bloggers. After two years of negotiations with judicial officials across the country, the Media Bloggers Association, a nonpartisan group with about 1,000 members working to extend the powers of the press to bloggers, has won credentials to rotate among his members. The trial of I. Lewis "Scooter" Libby, the highest-ranking Bush administration official to face criminal charges, could "catalyze" the association's efforts to win respect and access for bloggers in federal and state courthouses, said Robert Cox, the association's president. ${ }^{495}$

The Media Bloggers Association is "dedicated to promoting, protecting and educating its members; supporting the development of 'blogging' or 'citizen journalism' as a distinct form of media; and helping to extend the power of the press, with all the rights and responsibilities that entails, to every citizen."

\section{Court Premises}

The Kansas Supreme Court's rule on media court coverage prohibits recording of "interviews for broadcast in the hallways immediately adjacent to the entrances to the courtroom if passageways are blocked or judicial proceedings are disturbed thereby." ${ }^{297}$ The rule also forbids photographers from taking pictures "through the windows or open doors of the courtroom," 498 and authorizes judges to "ban cameras from the entire floor on which a proceeding is conducted." many states, and judges who enforce them can find themselves locked in First Amendment battles with the media. During a trial in Detroit, Michigan, for example, a judge cited a newspaper photographer for taking a picture of a witness outside the courthouse. ${ }^{500}$ The judge also cited the photographer's editor. ${ }^{501}$ A different judge who reviewed the contempt citations dismissed them. ${ }^{502}$ Lawyers for the newspaper had taken the position that, because the photographer had not used his camera

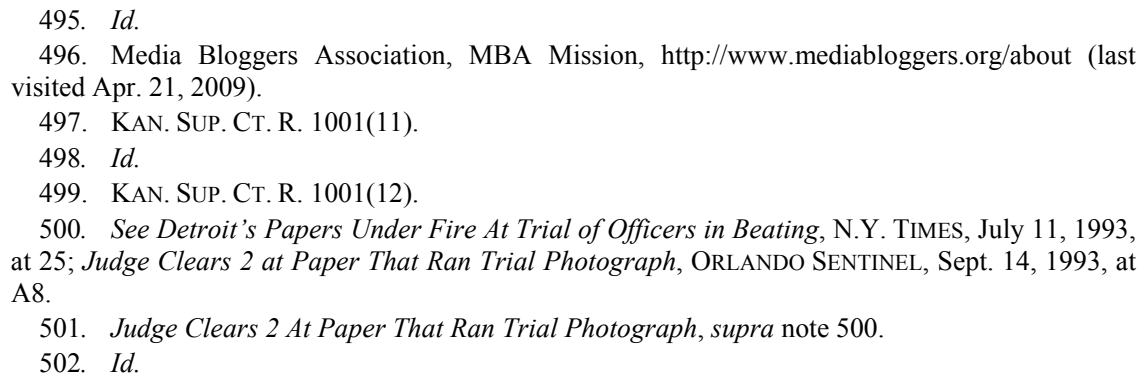


inside the courthouse, he was in compliance with applicable rules. ${ }^{503}$ They said that punishing the photographer for taking a picture on the public grounds outside the courthouse would violate the First Amendment. ${ }^{504}$

In 2004, when a grand jury was about to consider molestation charges against a celebrity in Santa Barbara County, California, a judge ordered that the media not publish photos of the grand jurors. ${ }^{505}$ The next day, a freelance photographer for the Associated Press was taking pictures outside the county courthouse when "[a] sheriff's deputy demanded the photographer's camera, flipped through the images and deleted one that the deputy decided violated the judge's order." 506 Tom Curley, president and chief executive officer of the Associated Press, speaking to journalists, commented: "The powerful have to be watched, and we are the watchers. And you don't need to have your notebook snatched by a policeman to know that keeping an eye on government activities has lately gotten a lot harder.",507

\section{CONCLUSION}

The trend of judicial decisions over many years in Kansas, as well as nationally, clearly has favored media and public access to court proceedings and records. The United States Supreme Court has recognized that courts historically have been open and that the benefits of openness are significant. ${ }^{508}$ Openness leads to public confidence in the judicial system. It enables the media to illuminate how the justice system works and to perform a checking function, holding judges and law enforcement accountable for their exercise of power and authority. A theme of court precedents nationally and in Kansas is that trial judges should take a broad view of their responsibilities. They do not serve merely to protect the fair trial rights of criminal defendants or the privacy interests of civil litigants. They also have an obligation to be as transparent as possible and facilitate a free flow of information and discourse about the judicial system.

The appellate courts have provided considerable guidance to judges and journalists on the free press/fair trial issue. When the Kansas

503. Detroit's Papers Under Fire At Trial of Officers in Beating, supra note 500.

504. Id.

505. Joel Campbell, Curley's Pledge: AP Ready to Join Fight, QuiLl, Sept. 2004, at 5, 5-6.

506. Id. at 5 .

507. Id. (citations omitted).

508. See supra Part II. 
Supreme Court made its decision in Fossey in 1981, for example, it established a plain, workable standard for determining whether a restriction on court access may be warranted. ${ }^{509}$ Basically, court proceedings and records must be open unless disclosure of information would pose "a clear and present danger to the fairness of the trial, and ... the prejudicial effect [of openness] cannot be avoided by reasonable alternative means." 510

Before imposing a restriction, a trial judge must give interested parties an opportunity to be heard. ${ }^{511}$ Then, the judge who decides to impose a restriction must support it by making specific findings on the record. ${ }^{512}$ The need for a hearing on proposed restraints on court access was highlighted in Alston in 1994, when the Kansas Supreme Court reversed a judge's gag order against the Atchison Daily Globe. ${ }^{513}$ The trial judge in Alston had time and opportunity to conduct a hearing before issuing a gag order against the Globe. ${ }^{514}$ He did not schedule a hearing, and the Kansas Supreme Court observed that there was "no clear showing that it was impossible to serve or notify the parties to be restrained. The judge failed to make the specific findings necessary for an ex parte order of prior restraint. $" 515$

Journalists are devoted to timely reporting on events of the day, including court cases. They may well focus on the interesting or sensational features of cases and, as a result, report information that damages trial participants. Ideally, the media would report at least as much about the procedural fairness that judges strive to ensure for defendants and private litigants. Nevertheless, under the First Amendment, appellate courts generally have recognized that the benefits of press freedom to report on the judicial system generally outweigh the costs. For example, in affirming the right of the media to intervene and object to judicially imposed restrictions on access, the Kansas Supreme Court said:

Allowing the news media to intervene in a criminal case ... may provide a trial court with the benefit of argument on the question of closure by an advocate of First Amendment and common-law interests. Such an argument would not necessarily be made by the State or the

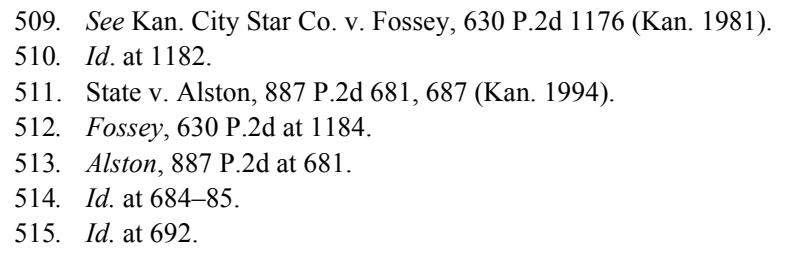


defense and might otherwise go entirely unnoticed. The news media may identify, or at least be the strongest proponent of an argument that there are ... "reasonable alternative means" to closure that would avoid the prejudicial effect on the defense or prosecution of the dissemination of information contained in the record or revealed during a proceeding. Other benefits to be derived from permitting the news media to intervene include: (1) allowing the court that is most familiar with events that may be unfolding rapidly in the case and in the community in which the case is pending to make a fully informed closure decision in the first instance, (2) less disruption in the processing of the criminal case because an appellate court would not be called upon prematurely to resolve a challenge by the news media while the criminal case is stayed pending the appellate court's decision, (3) an increase in judicial economy, and (4) a more efficient use of judicial resources. ${ }^{516}$

Many free press/fair trial controversies have been resolved over the years, but new and unsettled issues constantly arise. Trial judges in Kansas will continue to be challenged as media persistently demand access to proceedings and records, report with prejudicial effect on criminal defendants, or make disclosures that jeopardize the privacy of trial participants. At the same time, judges face an expanding media, ranging from bloggers who seek courtroom seats during high-profile cases, and who may well be packing cell-phone cameras, to citizenoperated websites that are devoted to disseminating public but sensitive court information, such as the identities of undercover agents. Fortunately for trial judges, ample, well-reasoned precedents exist to guide them in resolving the issues that they will face. 